\title{
The Potential Application of Green-Synthesized Metal Nanoparticles in Dentistry: A Comprehensive Review
}

\author{
Mohsen Yazdanian (D), ${ }^{1,2}$ Pouya Rostamzadeh, ${ }^{3}$ Mahdi Rahbar $\left(D^{4},{ }^{4}\right.$ Mostafa Alam (D), \\ Kamyar Abbasi $\mathbb{D}^{6}{ }^{6}$ Elahe Tahmasebi $\mathbb{D}^{1},{ }^{1,2}$ Hamid Tebyaniyan $\mathbb{D}^{1},{ }^{7}$ Reza Ranjbar $\mathbb{D}^{1,2}$ \\ Alexander Seifalian $\left(\mathbb{D},{ }^{8}\right.$ and Alireza Yazdanian $\mathbb{D}^{9}$ \\ ${ }^{1}$ Research Center for Prevention of Oral and Dental Diseases, Baqiyatallah University of Medical Sciences, Tehran, Iran \\ ${ }^{2}$ School of Dentistry, Baqiyatallah University of Medical Sciences, Tehran, Iran \\ ${ }^{3}$ Dental Students' Scientific Research Center (DSSRC), Tehran University of Medical Sciences, Tehran, Iran \\ ${ }^{4}$ Department of Restorative Dentistry, School of Dentistry, Ardabil University of Medical Sciences, Ardabil, Iran \\ ${ }^{5}$ Department of Oral and Maxillofacial Surgery, School of Dentistry, Shahid Beheshti University of Medical Sciences, Tehran, Iran \\ ${ }^{6}$ Department of Prosthodontics, School of Dentistry, Shahid Beheshti University of Medical Sciences, Tehran, Iran \\ ${ }^{7}$ Science and Research Branch, Islamic Azad University, Tehran, Iran \\ ${ }^{8}$ Nanotechnology and Regenerative Medicine Commercialization Centre (NanoRegMed Ltd), \\ The London Bioscience Innovation Centre, London, UK \\ ${ }^{9}$ Department of Veterinary, Science and Research Branch, Islamic Azad University, Tehran, Iran
}

Correspondence should be addressed to Elahe Tahmasebi; elahe.tahmasebi.delfan@gmail.com and Hamid Tebyaniyan; tebyan.hamid@yahoo.com

Received 17 October 2021; Revised 6 January 2022; Accepted 7 February 2022; Published 3 March 2022

Academic Editor: Valeria De Matteis

Copyright ( 2022 Mohsen Yazdanian et al. This is an open access article distributed under the Creative Commons Attribution License, which permits unrestricted use, distribution, and reproduction in any medium, provided the original work is properly cited.

\begin{abstract}
Orodental problems have long been managed using herbal medicine. The development of nanoparticle formulations with herbal medicine has now become a breakthrough in dentistry because the synthesis of biogenic metal nanoparticles (MNPs) using plant extracts can address the drawbacks of herbal treatments. Green production of MNPs such as Ag, Au, and Fe nanoparticles enhanced by plant extracts has been proven to be beneficial in managing numerous orodental disorders, even outperforming traditional materials. Nanostructures are utilized in dental advances and diagnostics. Oral disease prevention medicines, prostheses, and tooth implantation all employ nanoparticles. Nanomaterials can also deliver oral fluid or pharmaceuticals, treating oral cancers and providing a high level of oral healthcare. These are also found in toothpaste, mouthwash, and other dental care products. However, there is a lack of understanding about the safety of nanomaterials, necessitating additional study. Many problems, including medication resistance, might be addressed using nanoparticles produced by green synthesis. This study reviews the green synthesis of MNPs applied in dentistry in recent studies (2010-2021).
\end{abstract}

\section{Introduction}

Nanotechnology is a field of science that deals with nanometer-sized objects, which are referred to as nanoparticles (NPs). Nanomaterials are small solid particles having a dimension of 1-100 nanometers. Nanomaterials show promise in antibacterial therapy because of their improved and distinct physicochemical properties, including very small dimensions, huge surface area compared to their mass, and higher reactivity [1-5]. By adding many functional groups to the nanoparticle, the quality of products can be improved. Therefore, nanoproducts are widely used in different industrial, medical, and dentistry sectors. Nanobiotechnology is a unique method that has inspired the development of a variety of nanobiomaterials with applications in biology and medicine [6]. Despite their potential 
antibacterial properties, most methods for synthesizing these nanoparticles are costly and may have negative consequences for the environment, biological systems, and human health due to the usage of toxic and dangerous substances. As a result, "green" nanoparticle synthetization technologies have been created. Because no hazardous compounds are utilized, this alternative uses biological systems such as yeast, fungus, bacteria, and plant extracts, making it a safer and more environmentally friendly alternative to chemical approaches. Plant extracts are widely used for a variety of reasons, including their enormous and accessible reserves, global distribution, safe handling, availability of a diverse range of metabolites with high reducing potentials, and low waste and energy costs [7-9]. The broad application of medical nanosystems in different branches of dentistry, including prognosis, prevention, tissue regeneration, repair, and care, has been documented in numerous studies (Figure 1). For quality oral care, advancements in oral medicine nanosystems for individual prophylaxis are critical. Due to their broad-spectrum antibacterial capabilities, metal nanoparticles (MNPs) have been used in various dental applications. To achieve a greater antibacterial impact, tinier MNPs might release more of their ions. Many studies on the antibacterial activities of NPs have found that NPs have greater antibacterial activity in bacteria that are resistant to antibiotics. As a result, the use of nanoparticles in dentistry could be very beneficial [11-13]. Oral cosmetics with nanomaterials are used in toothpaste and other products to promote oral health. These procedures are applicable to nanoparticles and nanoparticle-based materials, with a focus on plaque management in periodontology and cariology. NPs have also been used in a variety of cosmetic products to help with enamel remineralization and dental hypersensitivity [14]. More than 75 bacterial and fungal strains have been linked to oral disorders. The oral microbiota had been altered by the accessible chemical reagents, resulting in diarrhea, vomiting, and tooth discoloration. Traditional medications can have a role in antibiotic treatment in general, but antibiotic resistance and undesirable side effects such as hypersensitivity, immunological suppression, and allergic reactions are growing concerns. As a result, scientists are attempting to create novel goods using natural materials. Plant-based biomolecules can inhibit the growth of oral infections, reduce tooth plaque, and reduce the symptoms of oral illnesses [15]. Biofilms are characterized as microbial communities that may house many bacterial and fungal species and are associated with nearly every surface on the planet, including human hard and soft tissues, and are embedded in extracellular polymeric substances. The accumulation of acidogenic biofilms on tooth surfaces, in particular, causes the enamel to dissolve, a process known as demineralization, which, if left untreated for long periods of time, can cause the development of caries. Controlling oral biofilm production is a difficult challenge, but nanotherapeutics has been employed successfully in recent years by adding nanoparticles into a variety of dental materials [7]. In this study, the dental application of green synthesis (GS) in the production of MNPs has been reviewed in recent studies (2010-2021).

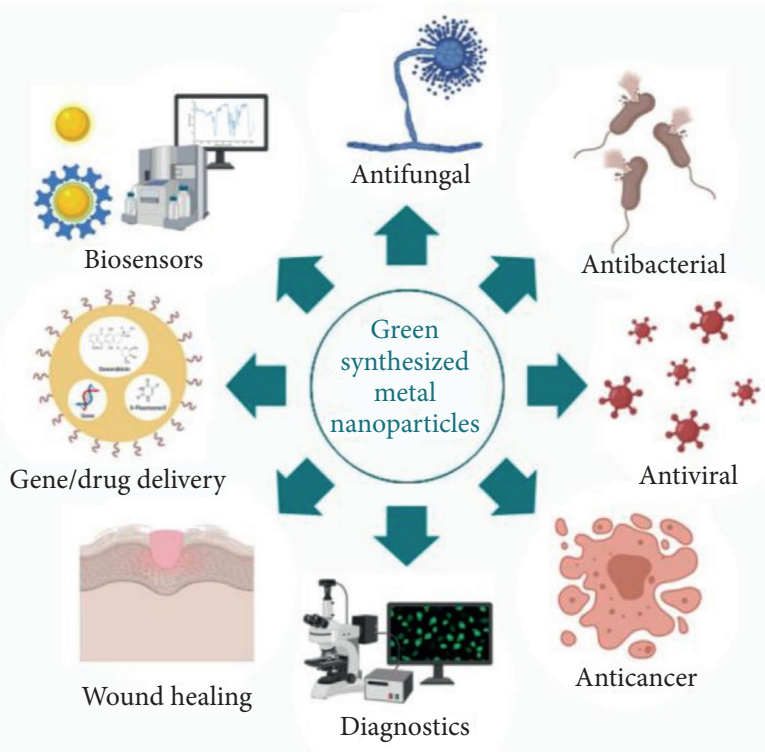

FIGURE 1: Green-synthesized metal nanoparticles' medical applications [10].

\section{Metal Nanoparticles}

MNPs are the most widely used inorganic NPs and can be considered a viable solution to antibiotic resistance. Furthermore, they attack a variety of biomolecules, posing a threat to the formation of resistant strains [16]. Because of their physicochemical properties and uses in biotechnology, metal nanoparticles (MNPs) created using green methods have risen in popularity. Nowadays, green-synthesizing NPs from plant extracts have become a critical concentration of researchers due to the low toxicity of these NPs in the human body and minimal hazardous influence on the environment. The shape and size of plant-derived NPs are more stable, and they yield more than the other approaches. Furthermore, some of these MNPs have demonstrated antibacterial action, regularly validated in recent years. Plant extracts have been employed as a reducing (RA) and stabilizer agent (SA) of NPs, allowing us to minimize toxicity in both the environment and the human body without the need for chemical agents [17].

2.1. Metal Nanoparticles' Characterization. Nanoparticles have been studied using a variety of approaches to determine their size, crystal structure, elemental content, and a range of other physical features. Physical attributes can be examined using more than one technique in numerous instances. Different strengths and limits of each methodology make selecting the best method difficult, and a combinatorial characterization is frequently required. Size and shape are two of the essential criteria addressed in the characterization of NPs. We may also assess the surface chemistry and estimate the size distribution, degree of aggregation, surface charge, and surface area. Other features and applications of NPs may be influenced by their size, size distribution, and organic ligands on their surfaces [18-20]. There are 
microscopy-based techniques (e.g., confocal laser scanning microscopy (CLSM), scanning electron microscopy (SEM), transmission electron microscopy [21], and atomic force microscopy (AFM)) [22], which provide information on the nanomaterials' size, shape, and crystal structure. Other approaches, such as magnetic procedures, are tailored to certain families of materials. SQUID, VSM, FMR, and XMCD are examples of these approaches. Many more techniques give further information on the nanoparticle samples' structure, elemental content, optical characteristics, and other common and more particular physical qualities. $\mathrm{X}$-ray, spectroscopy, and scattering techniques are examples of these techniques. Microstructure and dispersion (sizes and spatial distribution) of NPs must be described as a function of different process parameters to optimize the material qualities of MNPs [23]. UV/visible spectroscopy is a method for determining how much light is absorbed and dispersed by a substance. UV/Vis spectroscopy is a valuable method for identifying, characterizing, and investigating gold and silver plasmonic nanoparticles because their optical properties are sensitive to size, shape, concentration, agglomeration state, and refractive index near the nanoparticle surface. Transmission electron microscopy [21] is a highmagnification imaging technique that records the transmission of an electron beam through a sample. The preferred way for directly measuring the particle size, grain size, size distribution, and morphology of nanoparticles is to use TEM imaging. Sizing precision is usually within $3 \%$ of the actual value. DLS (dynamic light scattering) is a valuable technology for determining the properties of nanoparticles and other colloidal solutions. Because it offers information on the aggregation state of nanoparticle solutions, the hydrodynamic diameter is a valuable complement to other size studies such as TEM [24].

\subsection{Metal Nanoparticle Antibacterial Mechanisms.} Electrostatic interactions draw electropositive MNPs to the surface of electronegative bacterial cell walls. Apart from this, MNPs form a strong bond with membranes, resulting in the breakdown of cell walls and enhanced permeability. Furthermore, nanoparticles can transfer metal ions [25] into the cell from the extracellular area, disrupting physiological systems. MIs and NPs may produce reactive oxygen species (ROS) in the intracellular space. The oxidative stress causes glutathione to be oxidized, reducing bacteria's antioxidant defense system against ROS. As a result, MIs can interact with cell components (membranes, proteins, and DNA), disrupting cell functions [15]. MIs can create strong coordination bonds with the nitrogen, oxygen, and sulfur atoms found in organic compounds and biomolecules. MNPs have a broad spectrum of activity because the connections between MIs and biological molecules are often not specific [26].

\subsection{Disadvantages of the Application of Metal Nanoparticles.} Although NPs have been shown to have numerous advantages, they also have certain drawbacks, such as high costs, simple inhalation of nanoparticles, which can lead to lung disease, and changes in homeostasis. Nanotoxicity is a novel discipline of toxicology that studies the side effects of NPs, which may have toxicological consequences. The nanoparticles' tiny size makes them highly reactive and causes many adverse molecular effects. Most plant extract nanoparticles are unprocessed, yet they are not the functional molecules of choice for plant extracts. For the low-cost production of nanoparticles, all functional groups of plant extracts are analyzed. Analyzing which molecule is employed as a RA or SA and identifying the biological nanoparticles in charge of therapeutic purposes are quite complex. Assessing the system's overall toxicity in vivo should be a top goal. The compensating dose for greenproduced nanomaterials will be challenging to achieve with the reported dose. Green nanoparticles' long-term impacts on many clinicians will require more research in the future [27].

\section{Approaches for NPs' Synthesis}

3.1. Chemical Approach. Metallic precursors [28], RA, and SA are the primary components of the chemical method (inorganic and organic). Elemental hydrogen, the polyol process, ascorbate, sodium citrate, $\mathrm{NaBH}_{4}$, Tollens' reagent, and ethylene glycol-block copolymers are all utilized as RAs (Figure 2) [30].

3.2. Physical Approach. The most common physical method for the production of nanoparticles is a "top-down" mechanism in which the size of the material decreased using techniques such as ultrasonication, microwave (MW) irradiation, and electrochemical methods (Figure 2). The most well-known physical mechanisms are laser removal and evaporation condensation. A carrier gas is created by vaporizing the material inside a pontoon focused on the heater. Various $\mathrm{Au}, \mathrm{Ag}$, and $\mathrm{Cd}$ NPs have been produced and published using this dissipation buildup approach [31].

3.3. Green Approach. Traditional techniques have long been utilized, but studies have shown that GS is the most successful method for creating NPs because it has fewer risks of failure, is less expensive, and is easier to characterize. GS particles are distinct from those created by physical and chemical methods. GS, a bottom-up mechanism for creating MNPs, is similar to the chemical approach, in which biological components such as a plant extract replace a costly chemical RA. Biological organisms have great potential for producing NPs. Green reduction of MPs to NPs is favorable to the environment and is sustainable, chemical-free, less expensive, and scalable. Furthermore, the GS of NPs leads to the recycling of valuable metal salts such as $\mathrm{Au}$ and $\mathrm{Ag}$ present in steams of waste. Greenly coordinated NPs are presently preferred over conventionally supplied NPs due to their superior qualities. Because of their insecurity and ambiguous composition, additional chemicals that are hazardous and poisonous to human health and the environment might enhance particle reactivity and toxicity and produce undesired adverse health impacts. Green synthesis 


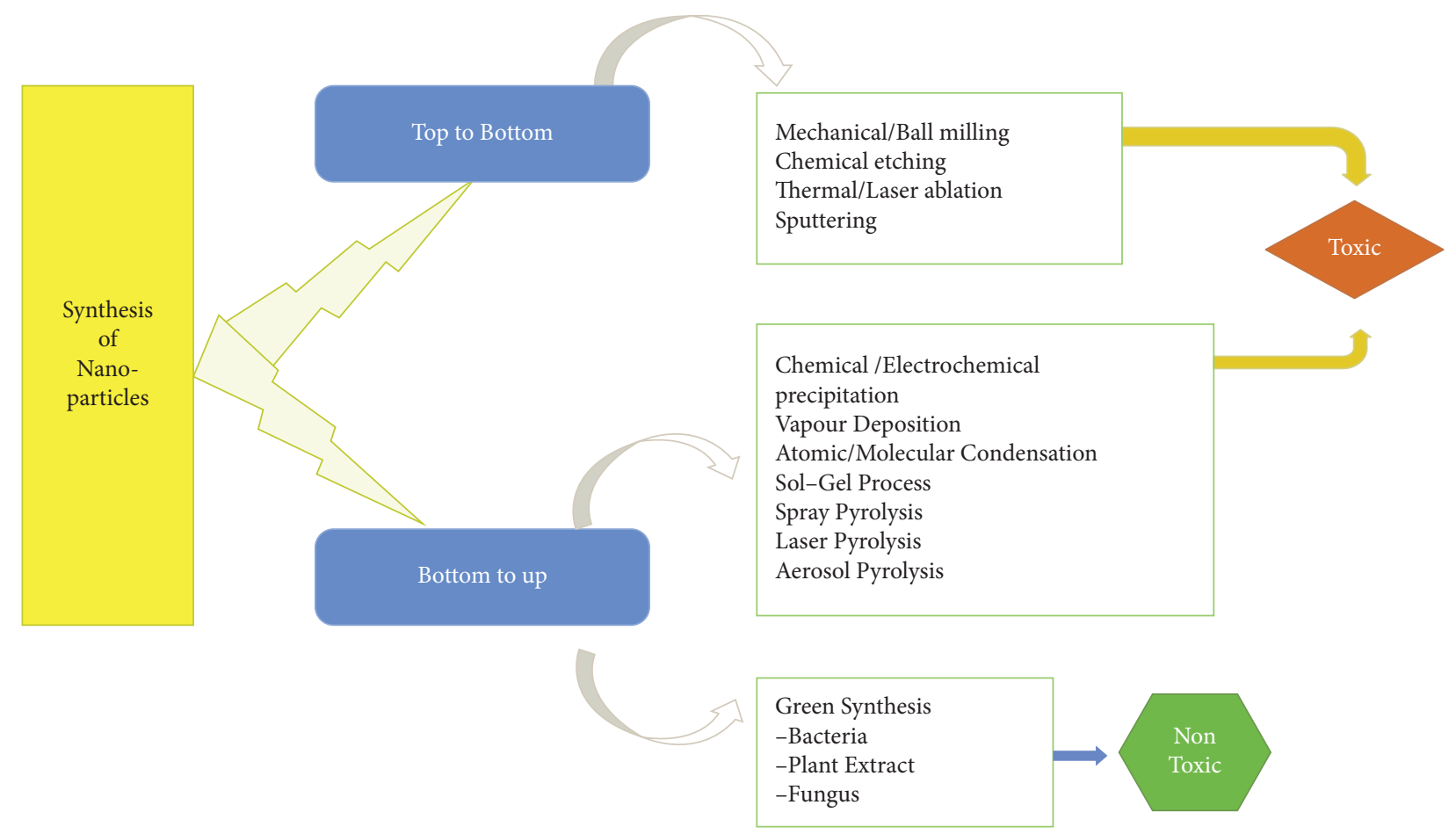

Figure 2: Various physical, chemical, and green approaches for the synthesis of NPs [29].

approaches are appealing because they can lessen nanoparticles' toxicity. As a result, the usage of plant extracts is becoming increasingly popular (Figure 2) [32, 33]. The collection and purification of the plant component of interest is the initial step in a typical plant-mediated metal nanoparticle production. Then, the plant is dried and pulverized. Deionized distilled water is generally poured into the plant powder according to the required concentration for plant extract production. This solution is then heated before being filtered. A particular volume of the extract is combined with the right amount of metal salt solution. The combination is heated to the required temperature for the specified duration while being thoroughly mixed. A color shift of the solution is achieved when metal ions are reduced to metal nanoparticles which may then be checked by UVvisible spectra (Figure 3) [10]. The dentistry application of green synthesis of plant-mediated metal is summarized in Table 1.

\subsubsection{Benefits of Plant-Delivered Green Synthesis over Mi-} croorganism-Delivered Methods. The reaction rate is relatively high in plant extract-based synthesis methods. Depending on the type of plant and the amount of plant, this reaction takes a few minutes and several hours, but a considerable time ( 2 or many days) is necessary for microbe cultivation in the microorganism-based approaches. This shows that this is a strategy that takes time. In addition to these microbes, some are pretty hazardous and pose a hazard to human health. Still, most of these are safe and benign to generate nanoparticles, such as Pseudomonas, Fusarium, and E. coli. Many plants are nearly always available in nature, particularly evergreen ones. Metal nanoparticles are synthesized by plant extracts mostly at ambient temperature, whereas the reaction mixture and culture medium must be heated when microorganisms synthesize metallic nanoparticles. Plant extracts, rather than microbes, are better suitable for mass production [86]. The most critical metal nanoparticles and their plant-based green synthesis and application in dentistry will be discussed in the following sections.

\section{Silver Nanoparticles}

Silver nanoparticles (AgNPs) have attracted commercial interest due to various characteristics, including a changeable surface-area-to-volume ratio, helpful in various biological and technological applications. They are widely used in the electrical industry and serve as effective catalysts. Many papers reveal their biological activity in medical applications, such as anticancer, antioxidant, and antibacterial effects. Silver has been utilized historically from ancient times, and it has been proven that silver is harmless to human cells in low doses. Several action mechanisms have been suggested in antibacterial AgNP activities, for example, the potential of AgNPs to attach bacterial walls and to cause structural changes in the cell membrane, the ability to damage and porous the cell-based membrane as a result of free AgNP radicals, and the ability to release silver ions in the inner cell to destruct various functions in the cell (Figure 4). An antifungal mechanism of AgNPs was earlier postulated against C. albicans in that AgNPs had high potential for disturbing the cell membrane and stopping the G2/M cell cycle of C. albicans [40]. Previously, AgNPs mainly were made through a chemical procedure involving the reduction 


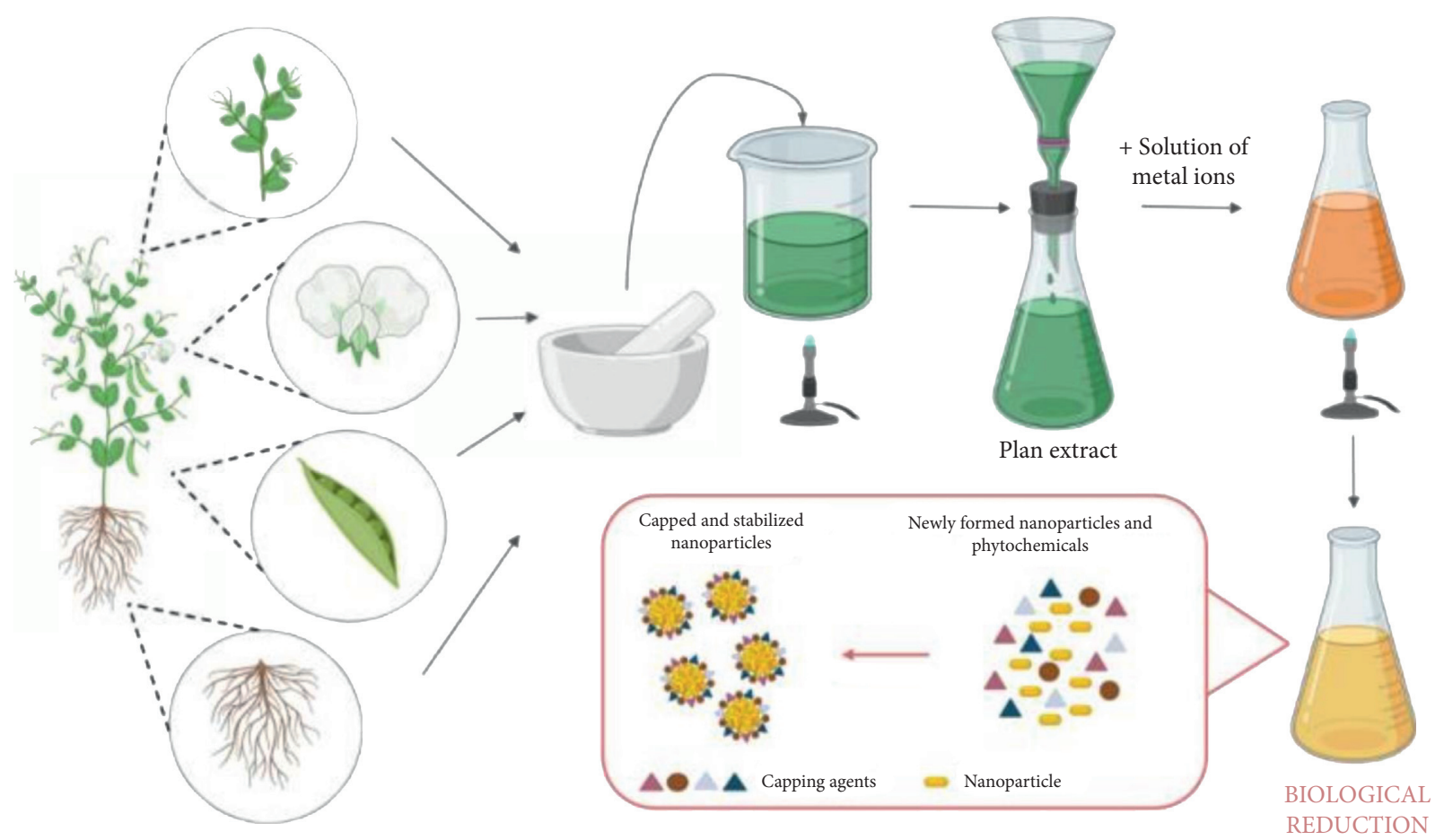

Figure 3: The typical process of plant-mediated green synthesis of metal nanoparticles [10].

of silver nitrate $\left(\mathrm{AgNO}_{3}\right)$ by a chemical reducing agent. Environmental resources, such as bacteria, plants, algae, and fungi, use the organic processes. The AgNPs' synthesis of microorganisms is easily scalable and naturally environmentally beneficial, although microorganism manufacturing is more expensive than plant extracts [40]. Plant extracts are used to make AgNPs because they include a lot of flavonoids, carbohydrates, sapogenins, and steroids which act as RA and biocapping chemicals that prevent nanoparticles from clumping together and allowing for greater size control (Figure 5). In general, obtaining AgNPs from plant extracts is a straightforward procedure. Plant fragments are gathered, sterile water cleaned, dried in the shade, and pulverized. The dried powder is boiled in deionized water to create the plant extract. The resulting infusion is filtered to remove any insoluble components. The solution containing $1 \mathrm{mM}$ $\mathrm{AgNO}_{3}$ is then supplemented with a particular volume of the plant extract. The color change of the medium (typically to dark brown) and the ultraviolet-visible (UV-Vis) spectra can be used to confirm the AgNPs' synthesis reaction. Repeated centrifugation procedures at 12,000 rpm for 15 minutes will easily collect AgNPs (Figure 6) [29].

Pomegranate (Punica granatum L.) has long been utilized as a reducing agent for $\mathrm{Ag}^{+}$ions. Pomegranate is known for its high phenolic content, including punicalagin, punicalin, ellagitannins, gallic acid, ellagic acid, and anthocyanins, which have anti-inflammatory qualities. Polyphenols, such as ellagic acid and gallic acid, are considered the elements responsible for the decrease of $\mathrm{Ag}^{+}$ions and the stabilization of AgNPs [7]. Rice (Oryza sativa L.) is a Poaceae family cereal plant. The rice husk is hard to preserve the kernel inside the rice grain [39]. The leftover product contains the interior endosperm as well as the exterior rice bran (RB) and rice germ (RG) after RH is removed. Many sections of the rice grain contain a high concentration of antioxidant and reducing active compounds. Suwan et al. used the rice extract to make AgNPs. They demonstrated that $\mathrm{RB}, \mathrm{RH}$, and RG aqueous extracts may be employed as reducing agents in the manufacture of silver nanoparticles (AgNPs). Their antimicrobial studies revealed that AgNPs derived from green synthesis catalyzed by rice extracts exhibit potent antibacterial action against $S$. mutans, a serious oral infection that causes caries. RB is the most effective and suitable component of the rice grain for AgNP production out of the three sections [40]. Jain and Mehata used green chemistry to make AgNPs using Ocimum sanctum (tulsi) leaf extracts and derivatives (tulsi) as distinct precursors. This is to see if the particles made just from the precursor quercetin have the same characteristics as the particles made from tulsi leaf extraction. AgNPs produced using the leaf extract and plain quercetin showed the same optical, morphological, and antibacterial characteristics, showing that the biomolecules (quercetin) contained in tulsi were largely responsible for reducing metal ions to MNPs [89]. Silver-mediated nanoparticles have been demonstrated to have a higher cytotoxicity in plants than gold, regardless of cell type. The size and shape of MNPs produced by plants had an impact on their cytotoxicity. Although cancer indications are acceptable, the therapeutic index of most nanoparticles is limited. MNPs synthesized from Butea monosperma, Abutilon inducum, Indoneesiella echioides, Melia azedarach, and Gossypium hirsutum are among the potential anticancer medications having an appropriate therapeutic indicator as a safety marker [90]. 
TABLE 1: Green synthesis of plant-mediated metal nanoparticles which have been used in dentistry.

\begin{tabular}{|c|c|c|c|c|c|}
\hline NP & Plant & Objective & Outcome & NP size & $\begin{array}{c}\text { Year/ } \\
\text { ref }\end{array}$ \\
\hline AgNP & Acacia senegal & $\begin{array}{l}\text { To make AgNPs, the unique } \\
\text { technique of utilizing tree exudates } \\
\text { containing a high quantity of } \\
\text { polysaccharides in gum Arabic } \\
\text { (GA) produced from the Acacia } \\
\text { senegal (L) wild tree was utilized. } \\
\text { The effect of synthesized AgNPs } \\
\text { was evaluated against } S \text {. mutans } \\
\text { isolates utilizing well diffusion and } \\
\text { microdilution methods. }\end{array}$ & $\begin{array}{l}\text { The synthesized NPs' strong } \\
\text { antibiotic activity against } S \text {. mutans } \\
\text { provides the door for creating new } \\
\text { dental care products. The tiny size } \\
\text { of the NPs further aids their } \\
\text { application in COVID-19 } \\
\text { pandemic containment. }\end{array}$ & $\begin{array}{c}<10 \mathrm{~nm} \text { (spherical } \\
\text { shape) }\end{array}$ & $\begin{array}{c}2021 / \\
{[34]}\end{array}$ \\
\hline AgNP & $\begin{array}{c}\text { Camellia sinensis (green } \\
\text { tea) }\end{array}$ & $\begin{array}{l}\text { This work aimed to make light- } \\
\text { colored } \mathrm{Ag}-\mathrm{SiO}_{2} \text { nanoparticles by } \\
\text { synthesizing AgNPs from the } \\
\text { green tea (GT) extract and coating } \\
\text { their surfaces with silica. }\end{array}$ & $\begin{array}{l}\mathrm{Ag}-\mathrm{SiO}_{2} \mathrm{NPs} \text { were shown to have } \\
\text { strong antibacterial activity against } \\
\text { S. mutans, with a } 600 \mathrm{~g} / \mathrm{mL} \text { MIC } \\
\text { and biofilm inhibition of around } \\
44 \% \text { ( } p \text { 0.05). Both NPs did not } \\
\text { cause cytotoxicity at the MIC } \\
\text { doses. }\end{array}$ & $\begin{array}{c}11 \mathrm{~nm} \text { (spherical } \\
\text { shape) }\end{array}$ & $\begin{array}{c}2020 / \\
{[35]}\end{array}$ \\
\hline AgNP & $\begin{array}{c}\text { Azadirachta indica and } \\
\text { Aloe vera }\end{array}$ & $\begin{array}{l}\text { The purpose of this study was to } \\
\text { see if AgNP made from neem and } \\
\text { Aloe vera had any antibacterial } \\
\text { activity against four dental } \\
\text { pathogens. }\end{array}$ & $\begin{array}{l}\text { AgNPs made from neem and Aloe } \\
\text { vera have been found to be efficient } \\
\text { against Streptococcus mutans and } \\
\text { Pseudomonas species }\end{array}$ & - & $\begin{array}{c}2019 / \\
{[36]}\end{array}$ \\
\hline AgNP & Viola serpens & $\begin{array}{l}\text { The objective of this study was to } \\
\text { see if silver nanoparticles } \\
\text { produced from the Viola serpens } \\
\text { plant have antibacterial and } \\
\text { antiplaque capabilities. } \\
\text { Antibacterial tests were used to } \\
\text { assess the efficacy of biologically } \\
\text { generated AgNPs against } \\
\text { recovered isolates. }\end{array}$ & $\begin{array}{l}\text { Compared to the reference } \\
\text { medicine, they were shown to be } \\
\text { relatively effective against the three } \\
\text { strains of } S \text {. mutans. }\end{array}$ & - & $\begin{array}{c}2018 / \\
{[37]}\end{array}$ \\
\hline AgNP & Curcuma aromatica & $\begin{array}{l}\text { To produce AgNPs, researchers } \\
\text { utilized Bacillus amyloliquefaciens } \\
\text { SJ14 culture (MAgNPs) and } \\
\text { extracted from Curcuma } \\
\text { aromatica rhizome (CAgNPs). } \\
\text { MIC, MBC, and antibiofilm } \\
\text { properties of AgNPs against } \\
\text { S. mutans were investigated. } \\
\text { PMMA/MAgNPs and PMMA/ } \\
\text { CAgNPs nanocomposite thin } \\
\text { films were tested for antimicrobial } \\
\text { and antibiofilm properties. }\end{array}$ & $\begin{array}{l}\text { When compared to CAgNPs, } \\
\text { MAgNPs were found to have better } \\
\text { antibacterial action. At doses of } 3 \mathrm{~g} / \\
\text { mL and } 50 \mathrm{~g} / \mathrm{mL} \text {, respectively, } \\
\text { MAgNPs and CAgNPs inhibited } \\
\text { S. mutans biofilm formation by } 99 \\
\text { and } 94 \text { percent, respectively. The } \\
\text { microbicidal activity of the } \\
\text { PMMA/MAgNP thin film was } \\
\text { found to be more significant. }\end{array}$ & $\begin{array}{c}\text { 10-30 (irregular } \\
\text { shape) }\end{array}$ & $\begin{array}{c}2018 / \\
{[38]}\end{array}$ \\
\hline AgNP & Oryza sativa L. (rice) & $\begin{array}{l}\text { Rice bran (RB), rice husk [39], and } \\
\text { rice germ (RG) aqueous extracts } \\
\text { were evaluated for their ability to } \\
\text { function as reducing agents in the } \\
\text { generation of AgNPs. }\end{array}$ & $\begin{array}{l}\text { The findings imply that aqueous } \\
\text { extracts of RB, RH, and RG might } \\
\text { be utilized as reducing agents in } \\
\text { AgNP production. }\end{array}$ & $346.4 \pm 36.8 \mathrm{~nm}$ & $\begin{array}{c}2018 / \\
{[40]}\end{array}$ \\
\hline
\end{tabular}


TABle 1: Continued.

\begin{tabular}{|c|c|c|c|c|c|}
\hline NP & Plant & Objective & Outcome & NP size & $\begin{array}{c}\text { Year/ } \\
\text { ref }\end{array}$ \\
\hline AgNP & $\begin{array}{l}\text { Punica granatum } \\
\text { L. (pomegranate) }\end{array}$ & $\begin{array}{l}\text { The objective was to develop, } \\
\text { characterize, and test novel } \\
\text { nanocomposites containing } \\
\text { AgNPs that were either associated } \\
\text { or not with calcium } \\
\text { glycerophosphate for antibacterial } \\
\text { and antibiofilm characteristics. } \\
\text { Following treatments, the MBC/ } \\
\text { MFC and biofilm density were } \\
\text { used to assess antimicrobial and } \\
\text { antibiofilm capabilities against } \\
\text { Candida albicans and } \\
\text { Streptococcus mutans. }\end{array}$ & $\begin{array}{l}\text { All of the extracts utilized were able } \\
\text { to produce AgNPs. Antimicrobial } \\
\text { and antibiofilm activities of } \\
\text { composites produced with peel } \\
\text { extracts were greatest against both } \\
\text { bacteria tested, and they performed } \\
\text { comparably to or better than } \\
\text { chlorhexidine. }\end{array}$ & $50 \mathrm{~nm}$ & $\begin{array}{c}2018 / \\
{[7]}\end{array}$ \\
\hline $\begin{array}{l}\mathrm{Ag}_{2} \mathrm{O} \\
\mathrm{NP}\end{array}$ & Ficus benghalensis & $\begin{array}{l}\text { The antibacterial activity of } \mathrm{Ag}_{2} \mathrm{O} \\
\text { NPs produced with the Ficus } \\
\text { benghalensis prop root extract } \\
\text { (FBPRE) as a RA and SA is } \\
\text { described and investigated, as well } \\
\text { as their antibacterial efficacy } \\
\text { against dental bacterial strains. }\end{array}$ & $\begin{array}{l}\text { The combination of FBPRE and } \\
\mathrm{Ag}_{2} \mathrm{O} \text { NPs has good antibacterial } \\
\text { activity against Streptococcus } \\
\text { mutans and Lactobacilli sp., two } \\
\text { dental pathogens. }\end{array}$ & $42.7 \mathrm{~nm}$ & $\begin{array}{c}2017 / \\
{[41]}\end{array}$ \\
\hline AgNP & Aloe vera & $\begin{array}{l}\text { The purpose of this study was to } \\
\text { compare the antibacterial } \\
\text { effectiveness of Aloe vera } \\
\text { nanoparticles to calcium } \\
\text { hydroxide in the treatment of } \\
\text { chronic endodontic infections. }\end{array}$ & $\begin{array}{l}\text { The antibacterial activity of AgNPs } \\
\text { from } A \text {. vera should prompt } \\
\text { further study into their application } \\
\text { as an intracanal medicament in } \\
\text { root canal therapy. }\end{array}$ & - & $\begin{array}{c}2017 / \\
{[42]}\end{array}$ \\
\hline AgNP & Tragia involucrata & $\begin{array}{l}\text { The AgNPs were made using a } \\
\text { simple green technique using an } \\
\text { aqueous extract of T. involucrata. } \\
\text { UV spectroscopy, particle size } \\
\text { measurement, zeta potential, and } \\
\text { TEM were used to demonstrate } \\
\text { the production of AgNPs. A single } \\
\text { gel diffusion technique was used to } \\
\text { test the extract's in vitro struvite } \\
\text { growth inhibitory efficacy. }\end{array}$ & $\begin{array}{l}\text { The findings suggested that an } \\
\text { aqueous extract of } T \text {. involucrata } \\
\text { and its AgNPs might be used to } \\
\text { treat patients with recurring stones. }\end{array}$ & $47 \mathrm{~nm}$ & $\begin{array}{c}2017 / \\
{[43]}\end{array}$ \\
\hline AgNP & Mangifera indica & $\begin{array}{l}\text { A novel green synthesis method } \\
\text { was utilized to make silver } \\
\text { nanoparticles from leaves of } \\
\text { Mangifera indica. The antibacterial } \\
\text { activity of AgNPs is tested on } \\
\text { Escherichia coli and Staphylococcus } \\
\text { aureus germs, and the hardness of } \\
\text { AgNP-reinforced GIC is } \\
\text { compared to ordinary GIC and } \\
\text { microsilver-reinforced GIC. }\end{array}$ & $\begin{array}{l}\text { As seen by the results, the AgNP- } \\
\text { reinforced GIC had a much higher } \\
\text { hardness, and the AgNPs were } \\
\text { shown to have an acceptable } \\
\text { antibacterial activity. }\end{array}$ & $32 \mathrm{~nm}$ & $\begin{array}{c}2017 / \\
{[44]}\end{array}$ \\
\hline AgNP & Prunus japonica & $\begin{array}{c}\text { A simple room-temperature } \\
\text { approach was utilized to produce } \\
\text { AgNPs from } \mathrm{AgNO}_{3} \text { at a low cost } \\
\text { and in an ecologically acceptable } \\
\text { way using the Prunus japonica } \\
\text { leaves' extract as an RA. }\end{array}$ & $\begin{array}{l}\text { The produced AgNPs have } \\
\text { antibacterial efficacy against tested } \\
\text { bacteria to varying degrees, with } \\
\text { Proteus vulgaris having the highest } \\
\text { activity. }\end{array}$ & $24 \mathrm{~nm}$ spherical & $\begin{array}{c}2017 / \\
{[45]}\end{array}$ \\
\hline AgNP & Ficus religiosa & $\begin{array}{l}\text { AgNPs were produced and } \\
\text { described utilizing the Ficus } \\
\text { religiosa leaf extract. }\end{array}$ & $\begin{array}{l}\text { In several cancer cell lines, the } \\
\text { AgNPs exhibited strong } \\
\text { antibacterial action as well as } \\
\text { cytotoxicity. }\end{array}$ & $21 \mathrm{~nm}$ & $\begin{array}{c}2017 / \\
{[15]}\end{array}$ \\
\hline
\end{tabular}


TABle 1: Continued.

\begin{tabular}{|c|c|c|c|c|c|}
\hline NP & Plant & Objective & Outcome & NP size & $\begin{array}{c}\text { Year/ } \\
\text { ref }\end{array}$ \\
\hline AgNP & Ficus carica & 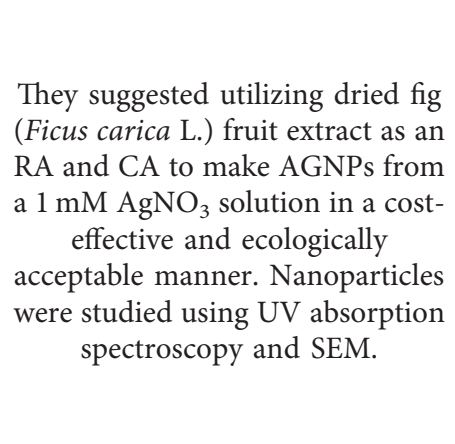 & $\begin{array}{l}\text { Silver nanoparticles were } \\
\text { successfully synthesized using the } \\
\text { dried fruit extract of Ficus carica. } \\
\text { According to the anticancer test, } \\
\text { the AgNPs reduced by the fig } \\
\text { extract showed a strong anticancer } \\
\text { effect against MCF7 cells, and } \\
\text { further animal acute toxicity } \\
\text { experiments indicate that the } \\
\text { aforementioned AgNPs are } \\
\text { toxicologically harmless when } \\
\text { given orally. }\end{array}$ & $54-89 \mathrm{~nm}$ & $\begin{array}{c}2017 / \\
{[46]}\end{array}$ \\
\hline AgNP & Psoralea corylifolia & 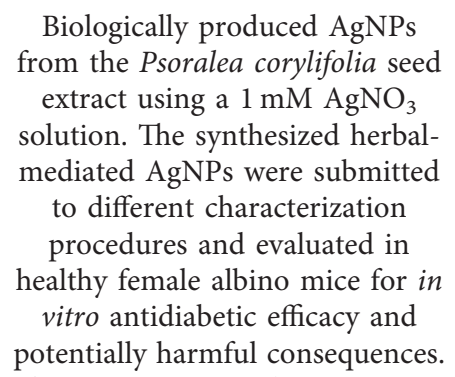 & $\begin{array}{l}\text { This research might lead to the } \\
\text { creation of valuable nanomedicines } \\
\text { to treat a variety of disorders and } \\
\text { highlight AgNPs' safety and } \\
\text { biocompatibility within biological } \\
\text { cells. }\end{array}$ & $\begin{array}{c}15-25 \mathrm{~nm} \\
\text { (average: } 18 \mathrm{~nm} \text { ) }\end{array}$ & $\begin{array}{c}2017 / \\
{[47]}\end{array}$ \\
\hline AgNP & Azadirachta indica & $\begin{array}{c}\text { The aim was to synthesize AgNPs } \\
\text { using the Azadirachta indica } \\
\text { aqueous leaf extract and } \\
\text { investigate their antibacterial } \\
\text { effects on human pathogenic } \\
\text { Escherichia coli and Staphylococcus } \\
\text { aureus. } \\
\text { Characterization of produced } \\
\text { nanoparticles using various } \\
\text { methods. }\end{array}$ & $\begin{array}{l}\text { Both Gram-positive and Gram- } \\
\text { negative pathogens were } \\
\text { susceptible to the AgNPs. }\end{array}$ & $34 \mathrm{~nm}$ & $\begin{array}{c}2016 / \\
{[48]}\end{array}$ \\
\hline AgNP & $\begin{array}{l}\text { Ficus benghalensis and } \\
\text { Azadirachta indica }\end{array}$ & $\begin{array}{l}\text { The agar well diffusion technique } \\
\text { was used to test the antibacterial } \\
\text { activity of green-produced AgNPs } \\
\text { against some bacteria. Cell } \\
\text { viability was studied to assess the } \\
\text { cytotoxic effect of green-produced } \\
\text { AgNPs. }\end{array}$ & $\begin{array}{l}\text { Gram-negative and Gram-positive } \\
\text { microorganisms exhibited } \\
\text { potential antibacterial action } \\
\text { against the NPs. The produced } \\
\text { AgNPs demonstrated } \\
\text { antiproliferative efficacy against the } \\
\text { MG-63 osteosarcoma cell line in a } \\
\text { dose-dependent manner. }\end{array}$ & $40-50 \mathrm{~nm}$ & $\begin{array}{c}2016 / \\
{[49]}\end{array}$ \\
\hline AgNP & Salix alba & $\begin{array}{l}\text { DAD was used to test the } \\
\text { antibacterial activity of these } \\
\text { biologically produced silver } \\
\text { nanoparticles. }\end{array}$ & $\begin{array}{l}\text { The antibacterial efficacy of these } \\
\text { manufactured silver nanoparticles } \\
\text { was demonstrated against bacteria } \\
\text { isolated from dental plaque. }\end{array}$ & $29-35 \mathrm{~nm}$ & $\begin{array}{c}2016 / \\
{[50]}\end{array}$ \\
\hline AgNP & Emblica officinalis & $\begin{array}{l}\text { The AgNPs were produced using } \\
\text { E. officinalis (fruit extract). The } \\
\text { nanoparticles were analyzed using } \\
\text { UV-Vis spectrophotometers, FTIR } \\
\text { measurements, and SEM and XRD } \\
\text { to determine the presence of } \\
\text { E. officinalis biomolecules } \\
\text { encapsulated in AgNPs. } \\
\text { DAD was used to evaluate the } \\
\text { antibacterial activity of the } \\
\text { produced AgNPs against the } \\
\text { isolates. }\end{array}$ & $\begin{array}{l}\text { The results showed that the } \\
\text { E. officinalis fruit extract is an } \\
\text { excellent bioreductant for the } \\
\text { production of AgNPs. The } \\
\text { produced AgNPs were found to } \\
\text { inhibit and have considerable } \\
\text { antibacterial activity against } \\
\text { bacterial strains. }\end{array}$ & $15 \mathrm{~nm}$ & $\begin{array}{c}2015 / \\
{[51]}\end{array}$ \\
\hline
\end{tabular}


TABle 1: Continued.

\begin{tabular}{|c|c|c|c|c|c|}
\hline NP & Plant & Objective & Outcome & NP size & $\begin{array}{c}\text { Year/ } \\
\text { ref }\end{array}$ \\
\hline AgNP & Justicia glauca & $\begin{array}{l}\text { The antimicrobial activities of } \\
\text { green-synthesized AgNPs and } \\
\text { drug-blended AgNPs against } \\
\text { dental caries and periodontal } \\
\text { disease-causing microorganisms } \\
\text { were tested. }\end{array}$ & $\begin{array}{l}\text { The antibacterial and antifungal } \\
\text { activities of AgNPs and drug- } \\
\text { mixed AgNPs were considerable. } \\
\text { The MIC of AgNPs against these } \\
\text { bacteria was found to be between } \\
25 \text { and } 75 \mathrm{~g} / \mathrm{mL} \text {. }\end{array}$ & $10-20 \mathrm{~nm}$ & $\begin{array}{c}2015 / \\
{[52]}\end{array}$ \\
\hline AgNP & Eucalyptus oleosa & $\begin{array}{c}\text { Aqueous } \mathrm{AgNO}_{3} \text { was mixed with } \\
\text { the E. oleosa leaf extract under } \\
\text { nonphotomediated conditions to } \\
\text { produce colloidal silver } \\
\text { nanoparticles. }\end{array}$ & $\begin{array}{l}\text { This study revealed that silver } \\
\text { nanoparticles may be produced by } \\
\text { adjusting key parameters, and } \\
\text { executing the synthesis method } \\
\text { under ideal conditions resulted in } \\
\text { silver nanoparticles with an } \\
\text { average size of } 21 \mathrm{~nm} \text {. }\end{array}$ & $21 \mathrm{~nm}$ & $\begin{array}{c}2015 / \\
{[53]}\end{array}$ \\
\hline AuNP & Anogeissus latifolia & $\begin{array}{l}\text { This study aimed to assess the } \\
\text { osteoinductive capacity and } \\
\text { analgesic effects of gold } \\
\text { nanoparticles (AuNPs) made with } \\
\text { phytochemicals from Anogeissus } \\
\text { latifolia. }\end{array}$ & $\begin{array}{l}\text { This study found that green- } \\
\text { synthesized AuNPs are effective } \\
\text { analgesic and bone-inducing } \\
\text { agents in implantation therapy. }\end{array}$ & $\begin{array}{l}50-60 \mathrm{~nm} \\
\text { (crystalline) }\end{array}$ & $\begin{array}{c}2020 / \\
{[54]}\end{array}$ \\
\hline AuNP & Salacia chinensis & $\begin{array}{l}\text { They looked at the osteoinductive } \\
\text { properties of gold nanoparticles } \\
\text { mediated by Salacia chinensis in } \\
\text { implant dentistry. }\end{array}$ & $\begin{array}{l}\text { The findings revealed that AuNPs } \\
\text { may be utilized as an efficient bone } \\
\text { inductive agent during dental } \\
\text { implant therapy since they are } \\
\text { stable, biocompatible, and } \\
\text { environmentally friendly. }\end{array}$ & $\begin{array}{c}1.5 \pm 0.8 \mathrm{~nm} \\
\text { (distorted } \\
\text { spherical shape) }\end{array}$ & $\begin{array}{c}2018 / \\
{[55]}\end{array}$ \\
\hline AgNP & Indigofera tinctoria & $\begin{array}{l}\text { On the lung cancer cell line A549, } \\
\text { the cytotoxic impact of the } \\
\text { I. tinctoria leaf extract and } \\
\text { nanoparticles was investigated. } \\
\text { The agar well diffusion technique } \\
\text { was used to assess antimicrobial } \\
\text { activity against bacterial and } \\
\text { fungal strains. Using the DPPH } \\
\text { technique, the antioxidant activity } \\
\text { of produced nanoparticles was } \\
\text { determined. }\end{array}$ & $\begin{array}{l}\text { It was discovered that when the } \\
\text { quantity of nanoparticles increases, } \\
\text { cell viability declines, and } \\
\text { nanoparticles have a more } \\
\text { damaging effect on cancer cells } \\
\text { than the pure leaf extract. The } \\
\text { nanoparticles produced had strong } \\
\text { antibacterial activity against all } \\
\text { investigated microbial strains to } \\
\text { various degrees. It was discovered } \\
\text { that nanoparticles have more } \\
\text { antioxidant activity than the leaf } \\
\text { extract. }\end{array}$ & $\begin{array}{l}\text { AgNP: } 9-26 \mathrm{~nm} \\
\quad(16.46 \mathrm{~nm})\end{array}$ & $\begin{array}{c}2018 / \\
{[56]}\end{array}$ \\
\hline AuNP & $\begin{array}{c}\text { Alternanthera } \\
\text { philoxeroides }\end{array}$ & $\begin{array}{l}\text { They used } A \text {. philoxeroides leaves } \\
\text { to make phytochemically gold } \\
\text { nanoparticles and tested the } \\
\text { positive effects of these biologically } \\
\text { synthesized nanoparticles against } \\
\text { various microbial strains. }\end{array}$ & $\begin{array}{l}\text { Overall, the findings point to a } \\
\text { successful production of green } \\
\text { nanoparticles as well as an } \\
\text { enhancement in gold nanoparticle } \\
\text { antibacterial efficacy. }\end{array}$ & $72.11 \pm 2.87 \mathrm{~nm}$ & $\begin{array}{c}2018 / \\
{[57]}\end{array}$ \\
\hline AuNP & Justicia glauca & $\begin{array}{l}\text { The research focuses on Justicia } \\
\text { glauca (aqueous leaf extract) } \\
\text { mediated AuNP production at } \\
\text { room temperature by treating } \\
\text { chloroaurate ions, which has an } \\
\text { antagonistic impact against oral } \\
\text { pathogenic bacteria and fungi } \\
\text { when taken with the medicines } \\
\text { azithromycin and clarithromycin. }\end{array}$ & $\begin{array}{l}\text { Against oral infections, AuNPs and } \\
\text { drug-conjugated AuNPs } \\
\text { demonstrated potential } \\
\text { antibacterial and antifungal action. } \\
\text { MIC values of biogenic AuNPs } \\
\text { against various oral infections were } \\
\text { found to be in the range of } \\
6.25-25 \mathrm{~g} / \mathrm{mL} \text {. }\end{array}$ & $32.5 \pm 0.25 \mathrm{~nm}$ & $\begin{array}{c}2017 / \\
{[6]}\end{array}$ \\
\hline
\end{tabular}


TABle 1: Continued.

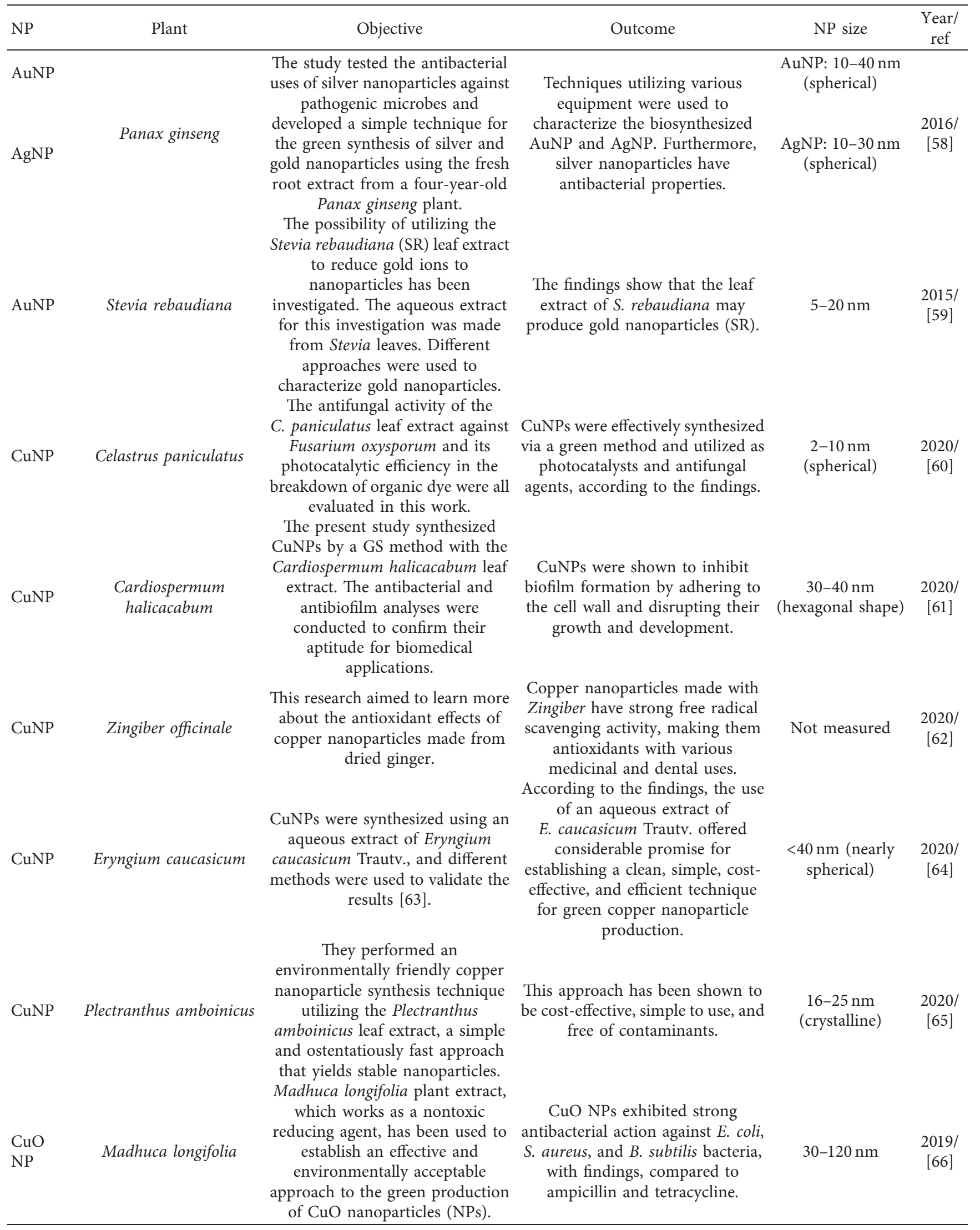


TABle 1: Continued.

\begin{tabular}{|c|c|c|c|c|c|}
\hline NP & Plant & Objective & Outcome & NP size & $\begin{array}{c}\text { Year/ } \\
\text { ref }\end{array}$ \\
\hline CuNP & Azadirachta indica & $\begin{array}{l}\text { CuNPs were produced using } \\
\text { Azadirachta indica leaf broth, and } \\
\text { the influence of various reaction } \\
\text { parameters on the conversion rate } \\
\text { and shape of the CuNPs was } \\
\text { investigated. }\end{array}$ & $\begin{array}{l}\text { The following were the optimal } \\
\text { conditions for synthesis: } 20 \% \text { leaf } \\
\text { broth, }\left[\mathrm{CuCl}_{2}\right]=7.5103 \mathrm{M}, \mathrm{pH} 6.6 \text {, } \\
\text { and temperature } 85^{\circ} \mathrm{C} \text {. The current } \\
\text { research might have a huge } \\
\text { influence on the ability to produce } \\
\text { metallic nanoparticles on a large } \\
\text { scale in the near future. }\end{array}$ & $\begin{array}{l}48 \text { nm (crystalline, } \\
\text { cubical shape) }\end{array}$ & $\begin{array}{c}2018 / \\
{[67]}\end{array}$ \\
\hline CuNP & Punica granatum & $\begin{array}{l}\text { The goal of this study was to use } \\
\text { plant extracts as RA and SA in the } \\
\text { GS of CuNPs. It would also look at } \\
\text { the antibacterial properties of the } \\
\text { CuNPs that had been produced. }\end{array}$ & $\begin{array}{l}\text { The copper nanoparticles can be } \\
\text { easily produced using the Punica } \\
\text { granatum fruit rind extract and } \\
\text { may be employed as effective } \\
\text { antibacterial agents against } \\
\text { Staphylococcus aureus. }\end{array}$ & $56-59 \mathrm{~nm}$ & $\begin{array}{c}2018 / \\
{[68]}\end{array}$ \\
\hline CuNP & Eclipta prostrata & $\begin{array}{l}\text { This study described the invention } \\
\text { of a technique for making CuNPs } \\
\text { by combining copper acetate } \\
\text { solution with the Eclipta prostrata } \\
\text { leaf extract without the need for a } \\
\text { surfactant or external energy. }\end{array}$ & $\begin{array}{l}\text { The antioxidant potential of the } \\
\text { biosynthesized CuNPs was } \\
\text { impressive. Similarly, in vitro } \\
\text { anticancer experiments revealed } \\
\text { that produced CuNPs had } \\
\text { cytotoxicity against HepG } 2 \text { cells. } \\
\text { The results of this work show that } \\
\text { biosynthesized CuNPs made from } \\
\text { E. prostrata extracts might be } \\
\text { utilized for medicinal purposes, } \\
\text { making them a potential } \\
\text { nanomaterial. }\end{array}$ & $\begin{array}{l}23-57 \mathrm{~nm} \text { (face- } \\
\text { centered cubic } \\
\text { structure) }\end{array}$ & $\begin{array}{c}2017 / \\
{[28]}\end{array}$ \\
\hline CuNP & Citrus medica Linn. & $\begin{array}{l}\text { They developed a safe and low-cost } \\
\text { technique for the production of } \\
\text { CuNPs utilizing citron juice. } \\
\text { CuNPs were tested for } \\
\text { antibacterial activity. }\end{array}$ & $\begin{array}{l}\text { CuNPs produced by this method } \\
\text { showed considerable inhibitory } \\
\text { efficacy against tested } \\
\text { microorganisms. }\end{array}$ & $20 \mathrm{~nm}$ & $\begin{array}{c}2015 / \\
{[69]}\end{array}$ \\
\hline $\begin{array}{l}\mathrm{Fe}_{3} \mathrm{O}_{4} \\
\mathrm{NPs}\end{array}$ & Euphorbia hirta & $\begin{array}{l}\text { In the green production of } \\
\text { magnetic iron oxide nanoparticles, } \\
\text { they employed the Euphorbia hirta } \\
\text { leaf extract }\left(\mathrm{Fe}_{3} \mathrm{O}_{4} \mathrm{NPs}\right)\end{array}$ & $\begin{array}{l}\text { The antibacterial activity of the } \\
\text { produced iron oxide nanoparticles } \\
\text { was tested against various bacterial } \\
\text { and fungal pathogens, with highly } \\
\text { encouraging results. }\end{array}$ & $\begin{array}{l}25-80 \mathrm{~nm} \text { (cavity- } \\
\text { like structure) }\end{array}$ & $\begin{array}{c}2020 / \\
{[70]}\end{array}$ \\
\hline FeNP & $\begin{array}{c}\text { Rose, Azadirachta indica } \\
\text { (neem), carom, Syzygium } \\
\text { aromaticum (clove) }\end{array}$ & $\begin{array}{l}\text { These particles were made using } \\
\text { mango leaves, rose leaves, neem } \\
\text { leaves, carom seeds, and clove } \\
\text { buds in an environmentally } \\
\text { friendly green synthesis process at } \\
70^{\circ} \mathrm{C} \text { with continual stirring and } \\
\text { atmospheric pressure. }\end{array}$ & $\begin{array}{l}\text { The size of Fe particles grew larger } \\
\text { as the concentration of } \\
\text { polyvinylpyrrolidone (PVP) rose, } \\
\text { according to the findings of the } \\
\text { experiments. The presence of PVP } \\
\text { allows particles at the micro-/ } \\
\text { nanoscale to maintain their } \\
\text { crystalline structure after } 3 \text { to } 4 \\
\text { months of preparation. }\end{array}$ & $\begin{array}{l}12-28 \mathrm{~nm} \\
\text { (crystalline) }\end{array}$ & $\begin{array}{c}2019 / \\
{[71]}\end{array}$ \\
\hline FeONP & Moringa oleifera & $\begin{array}{l}\text { They used the Moringa oleifera leaf } \\
\text { extract to make FeONPs and } \\
\text { examined their fluoride ion } \\
\text { adsorption potential, comparing } \\
\text { their effectiveness to that of a } \\
\text { commercially available adsorbent. }\end{array}$ & $\begin{array}{l}\text { The regeneration process revealed } \\
\text { that FeONPs may be reused three } \\
\text { times in the fluoride ion adsorption } \\
\text { method. Due to its adsorption } \\
\text { characteristics and the shortest } \\
\text { contact time to reach equilibrium, } \\
\text { FeONP is a potential material for } \\
\text { fluoride ion removal. }\end{array}$ & $4.14 \mathrm{~nm}$ & $\begin{array}{c}2018 / \\
{[72]}\end{array}$ \\
\hline
\end{tabular}


TABle 1: Continued.

\begin{tabular}{|c|c|c|c|c|c|}
\hline NP & Plant & Objective & Outcome & NP size & $\begin{array}{c}\text { Year/ } \\
\text { ref }\end{array}$ \\
\hline $\begin{array}{l}\mathrm{Fe}_{3} \mathrm{O}_{4} \\
\mathrm{NPs}\end{array}$ & Couroupita guianensis & $\begin{array}{l}\text { They have proposed utilizing the } \\
\text { C. guianensis aqueous fruit extract } \\
\text { to produce magnetic } \mathrm{Fe}_{3} \mathrm{O}_{4} \mathrm{NPs} \\
\text { for antibacterial and theranostic } \\
\text { cancer applications. }\end{array}$ & $\begin{array}{c}\text { These } \mathrm{Fe}_{3} \mathrm{O}_{4} \text { NPs demonstrated } \\
\text { outstanding bactericidal activity } \\
\text { against various human diseases, } \\
\text { demonstrating their antibacterial } \\
\text { potential. } \mathrm{Fe}_{3} \mathrm{O}_{4} \text { NPs had a } \\
\text { substantial dose-dependent } \\
\text { cytotoxic effect on treated human } \\
\text { hepatocellular carcinoma cells } \\
\text { (HepG2). }\end{array}$ & $\begin{array}{l}17 \pm 10 \mathrm{~nm} \\
\text { (crystalline) }\end{array}$ & $\begin{array}{c}2017 / \\
{[73]}\end{array}$ \\
\hline FeNP & $\begin{array}{l}\text { Syzygium aromaticum } \\
\text { (clove), Azadirachta } \\
\text { indica (neem), Camellia } \\
\text { sinensis (green tea) }\end{array}$ & $\begin{array}{l}\text { The activity of popular natural } \\
\text { items such as clove buds, neem } \\
\text { leaves, and green tea leaves against } \\
\text { S. mutans was investigated. } \\
\text { S. mutans was treated with several } \\
\text { combinations of therapies. }\end{array}$ & $\begin{array}{l}\text { The study found that adding FeNP } \\
\text { to an antibacterial treatment boosts } \\
\text { its action. }\end{array}$ & - & $\begin{array}{c}2017 / \\
{[74]}\end{array}$ \\
\hline $\begin{array}{l}\mathrm{TiO}_{2} \\
\mathrm{NP}\end{array}$ & $\begin{array}{l}\text { Azadirachta indica twigs, } \\
\text { Ficus benghalensis, and } \\
\text { Syzygium aromaticum }\end{array}$ & $\begin{array}{l}\mathrm{TiO}_{2} \text { nanoparticles (NPs) were } \\
\text { green-synthesized utilizing } \\
\text { Azadirachta indica twigs, Ficus } \\
\text { benghalensis, and Syzygium } \\
\text { aromaticum extracts. } \\
\mathrm{TiO}_{2} \text { NPs were evaluated for } \\
\text { antibacterial and antibiofilm } \\
\text { properties against bacteria } \\
\text { (Streptococcus mutans and } \\
\text { Citrobacter freundii) and fungi } \\
\text { (Candida albicans) }\end{array}$ & $\begin{array}{l}\text { According to this study, greenly } \\
\text { produced } \mathrm{TiO}_{2} \text { NPs have } \\
\text { outstanding antibacterial and } \\
\text { antibiofilm characteristics. }\end{array}$ & $\begin{array}{c}18.95 \mathrm{~nm} \\
\text { (crystalline) }\end{array}$ & $\begin{array}{c}2020 / \\
{[75]}\end{array}$ \\
\hline $\begin{array}{l}\mathrm{TiO}_{2} \\
\mathrm{NP}\end{array}$ & Citrus aurantifolia & $\begin{array}{l}\text { This article focused on the } \\
\text { production of } \mathrm{TiO}_{2} \text { fillers and their } \\
\text { potential use in light-curing dental } \\
\text { composite materials. }\end{array}$ & $\begin{array}{l}\text { The findings revealed that } \mathrm{TiO}_{2} \\
\text { nanohybrids might be utilized as } \\
\text { excellent fillers for light-curing } \\
\text { dental nanohybrid composite } \\
\text { materials to improve their physical } \\
\text { characteristics, in addition to their } \\
\text { antibacterial, hydrophilic, and self- } \\
\text { cleaning capabilities. }\end{array}$ & $\begin{array}{c}30-40 \mathrm{~nm} \\
\text { (crystalline) }\end{array}$ & $\begin{array}{c}2019 / \\
{[76]}\end{array}$ \\
\hline $\begin{array}{l}\mathrm{TiO}_{2} \\
\mathrm{NP}\end{array}$ & Echinacea purpurea & $\begin{array}{l}\text { An aqueous solution of the } \\
\text { Echinacea purpurea herbal extract } \\
\text { was used as a bioreduction in this } \\
\text { work to biosynthesize titanium } \\
\text { dioxide nanoparticles. } \\
\text { The aqueous extract of }\end{array}$ & $\begin{array}{l}\text { UV-Vis spectroscopy, FTIR } \\
\text { spectroscopy, and TXRF were used } \\
\text { to establish the existence of } \mathrm{TiO}_{2} \\
\text { nanoparticles. }\end{array}$ & $120 \mathrm{~nm}$ & $\begin{array}{c}2017 / \\
{[77]}\end{array}$ \\
\hline $\begin{array}{l}\mathrm{TiO}_{2} \\
\mathrm{NP}\end{array}$ & $\begin{array}{l}\text { Acanthophyllum } \\
\text { laxiusculum }\end{array}$ & $\begin{array}{l}\text { Acanthophyllum laxiusculum was } \\
\text { used in this work to create green or } \\
\text { environmentally friendly } \mathrm{TiO}_{2} \\
\text { NPs. The sol-gel process, one of } \\
\text { the most extensively utilized in the } \\
\text { nanofield, was employed to make } \\
\text { titanium dioxide nanoparticles. }\end{array}$ & $\begin{array}{l}\text { UV-Vis absorption spectra were } \\
\text { used to determine } \mathrm{TiO}_{2} \\
\text { nanospheres and then confirmed } \\
\text { using diffuse reflectance } \\
\text { spectroscopy. }\end{array}$ & $\begin{array}{c}25 \mathrm{~nm} \\
\text { (crystalline) }\end{array}$ & $\begin{array}{c}2016 / \\
{[78]}\end{array}$ \\
\hline ZnONP & Deverra tortuosa & $\begin{array}{l}\text { Using the MTT test, the potential } \\
\text { anticancer activity was examined } \\
\text { in vitro against two cancer cell } \\
\text { lines (human colon } \\
\text { adenocarcinoma "Caco-2" and } \\
\text { human lung adenocarcinoma } \\
\text { "A549"), as well as human lung } \\
\text { fibroblast cell line (WI38). }\end{array}$ & $\begin{array}{l}\text { Against the two cancer cell lines } \\
\text { tested, both aqueous extract and } \\
\text { ZnONPs demonstrated significant } \\
\text { selective cytotoxicity. }\end{array}$ & 9-31 nm (15.41) & $\begin{array}{c}2020 / \\
{[79]}\end{array}$ \\
\hline
\end{tabular}


TABLE 1: Continued.

\begin{tabular}{|c|c|c|c|c|c|}
\hline NP & Plant & Objective & Outcome & NP size & $\begin{array}{c}\text { Year/ } \\
\text { ref }\end{array}$ \\
\hline $\mathrm{ZnONP}$ & Dysphania ambrosioides & $\begin{array}{l}\text { ZnONPs were synthesized } \\
\text { utilizing a green synthesis } \\
\text { technique, including Dysphania } \\
\text { ambrosioides extract. } \\
\text { Their antibacterial properties were } \\
\text { tested against bacteria such as } \\
\text { S. aureus, S. epidermidis, E. coli, } \\
\text { and Pseudomonas aeruginosa, as } \\
\text { well as bacteria commonly found } \\
\text { in human mouths and linked to } \\
\text { dental conditions. }\end{array}$ & $\begin{array}{l}\text { This report discussed the structural } \\
\text { properties of zinc oxide } \\
\text { nanoparticles (ZnONPs) } \\
\text { According to the antibacterial test, } \\
\text { most of the bacterial strains utilized } \\
\text { in this investigation were } \\
\text { susceptible to synthetic and } \\
\text { commercial NPs, with Prevotella } \\
\text { intermedia being the most sensitive } \\
\text { to ZnONPs. }\end{array}$ & $\begin{array}{c}\text { 5-30 nm (quasi- } \\
\text { spherical) }\end{array}$ & $\begin{array}{c}2020 / \\
{[80]}\end{array}$ \\
\hline $\mathrm{ZnONP}$ & Sesamum indicum L. & $\begin{array}{l}\text { They described that entire } \\
\text { vegetative portions of Sesamum } \\
\text { indicum L. were used to produce } \\
\text { ZnONPs. In this work, aqueous } \\
\text { extracts of several sections of } \\
\text { S. indicum were utilized to make } \\
\text { nanoparticles. }\end{array}$ & $\begin{array}{l}\text { This study will result in the } \\
\text { development of cost-effective } \\
\text { ZnONP synthesis with possible } \\
\text { further exploration to serve } \\
\text { humankind. }\end{array}$ & - & $\begin{array}{c}2019 / \\
{[81]}\end{array}$ \\
\hline $\mathrm{ZnONP}$ & Juglans regia $\mathrm{L}$. & $\begin{array}{l}\text { Juglans regia L. leaf extract was } \\
\text { used in the green production of } \\
\text { zinc oxide nanoparticles. The } \\
\text { characteristics of zinc oxide } \\
\text { nanoparticles produced using both } \\
\text { green and chemical techniques } \\
\text { were compared. }\end{array}$ & $\begin{array}{l}\mathrm{ZnO} \text { nanoparticles produced using } \\
\text { a green approach had a more } \\
\text { substantial antibacterial impact } \\
\text { than chemically manufactured } \\
\mathrm{ZnO} \text { nanoparticles. The } \\
\text { cytotoxicity of } \mathrm{ZnO} \text { nanoparticles } \\
\text { generated using the green } \\
\text { approach was lower than that of } \\
\text { chemically synthesized } \mathrm{ZnO} \\
\text { nanoparticles. }\end{array}$ & $\begin{array}{l}45-65 \mathrm{~nm} \\
\text { (spherical) }\end{array}$ & $\begin{array}{c}2019 / \\
{[82]}\end{array}$ \\
\hline ZnONP & Salvadora persica & $\begin{array}{l}\text { Under ambient circumstances, } \\
\text { Salvadora persica extract was used } \\
\text { as a mediator in the production of } \\
\text { ZnONPs. The MTT assay was } \\
\text { applied to test the cytotoxic } \\
\text { activity of the biosynthesized } \\
\text { nanoparticles against the HT-29 } \\
\text { cancer cell line. }\end{array}$ & $\begin{array}{l}\text { UV-Vis investigations of these } \\
\text { specific nanoparticles indicated the } \\
\text { production of } \mathrm{ZnO} \text { nanoparticles. } \\
\text { The findings revealed that the } \\
\text { toxicity of manufactured } \\
\text { nanoparticles is proportional to } \\
\text { their concentration. }\end{array}$ & $\begin{array}{l}60-130 \mathrm{~nm} \\
\text { (hexagonal) }\end{array}$ & $\begin{array}{c}2019 / \\
{[83]}\end{array}$ \\
\hline $\mathrm{ZnNP}$ & Lavandula vera & $\begin{array}{l}\text { The ZnNPs were produced } \\
\text { utilizing a GS method in the } \\
\text { presence of the Lavandula vera } \\
\text { leaf extract. The median fatal dose } \\
\text { of ZnNPs and subacute toxicity } \\
\text { were established using a variety of } \\
\text { tests. }\end{array}$ & $\begin{array}{l}\text { The results showed that changes in } \\
\text { OS were unrelated to the caspase } \\
\text { pathway and that the dosage of } \\
\text { biogenic ZnNPs with no observable } \\
\text { adverse effects (NOAEL) in a 14- } \\
\text { day subacute toxicity trial was less } \\
\text { than } 1 \mathrm{~g} / \mathrm{kg} \text {. }\end{array}$ & $30-80 \mathrm{~nm}$ & $\begin{array}{c}2019 / \\
{[84]}\end{array}$ \\
\hline $\mathrm{ZnONP}$ & Costus pictus D. Don & $\begin{array}{l}\text { Green-synthesized ZnONPs were } \\
\text { tested against bacteria and two } \\
\text { fungal species, including Candida } \\
\text { albicans. The antitumor effect of } \\
\text { the produced ZnONPs was } \\
\text { investigated in mice with Dalton's } \\
\text { lymphoma ascites (DLA). }\end{array}$ & $\begin{array}{l}\text { When tested using the DAD } \\
\text { technique, the green-synthesized } \\
\text { ZnNPs demonstrate good } \\
\text { antibacterial efficacy against } \\
\text { bacterial and fungal species. The } \\
\text { ZnONPs have been shown to have } \\
\text { an anticancer effect against DLA } \\
\text { cells. }\end{array}$ & $20-80 \mathrm{~nm}(40 \mathrm{~nm})$ & $\begin{array}{c}2018 / \\
{[85]}\end{array}$ \\
\hline
\end{tabular}

4.1. Applications in Dentistry. The antimicrobial characteristics of silver nanoparticles (AgNPs) have been thoroughly explored, and they can be used in a variety of dental procedures. In vitro studies demonstrate that AgNPs have a strong antibacterial effect when coupled with dental materials, including acrylic resins, nanocomposites, adhesives, resin comonomers, intracanal medications, and implant coatings. Furthermore, due to their anticancer capabilities, AgNPs are promising tools in managing oral malignancies [91]. In endodontics, AgNP was utilized as a disinfectant to eliminate bacteria, toxins, and debris from the root canal system to hinder microbial development and prevent infection. This fast expansion of the AgNP usage in endodontic substances has been mainly owing to its demonstrated 


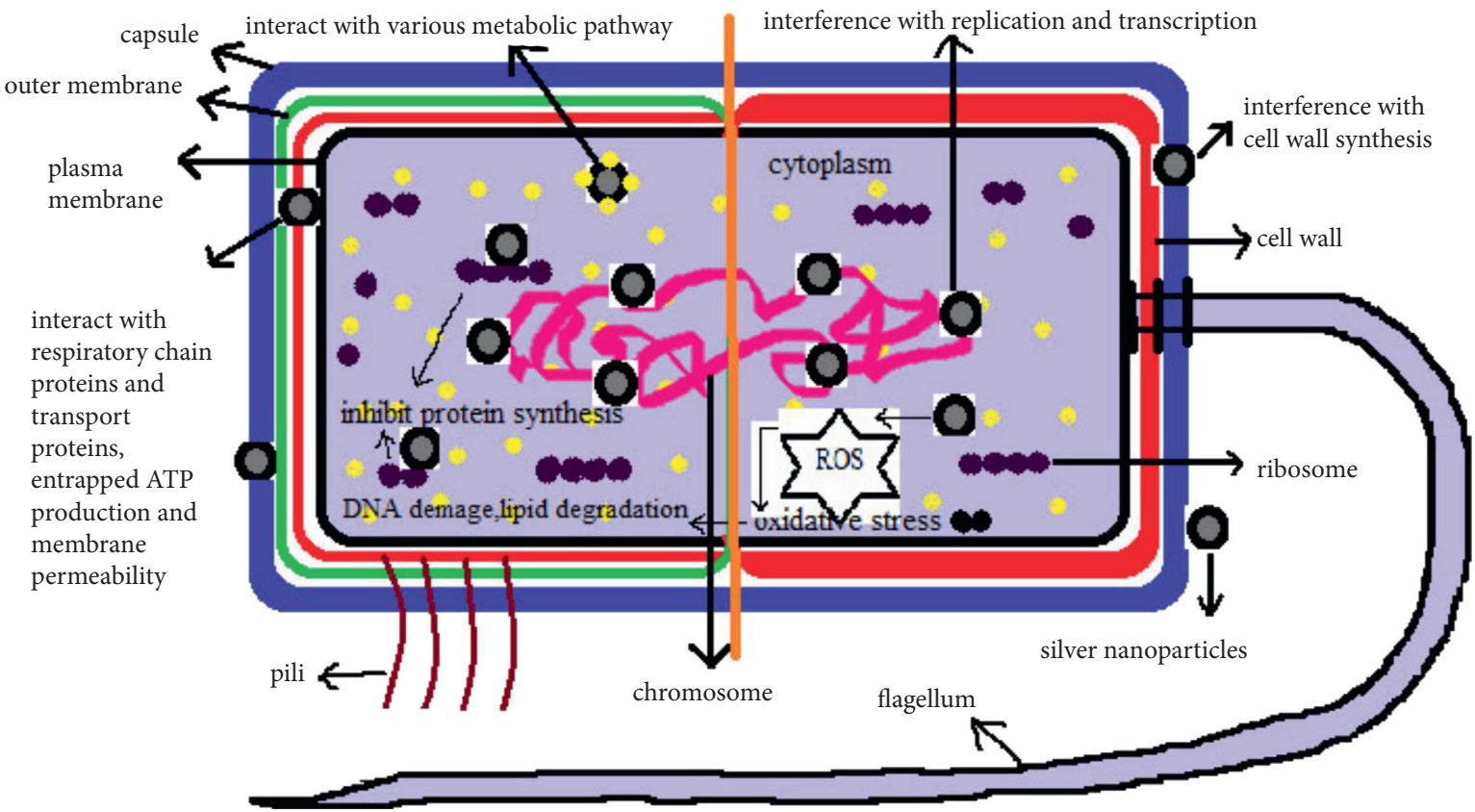

FIgURE 4: Antibacterial mechanism of silver nanoparticles [87].

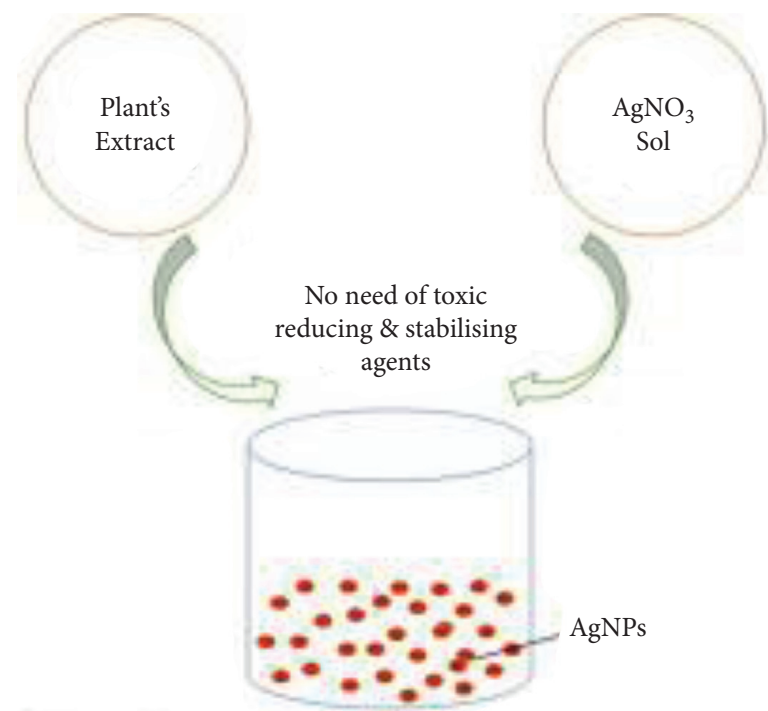

Figure 5: Green synthesis of AgNPs [29].
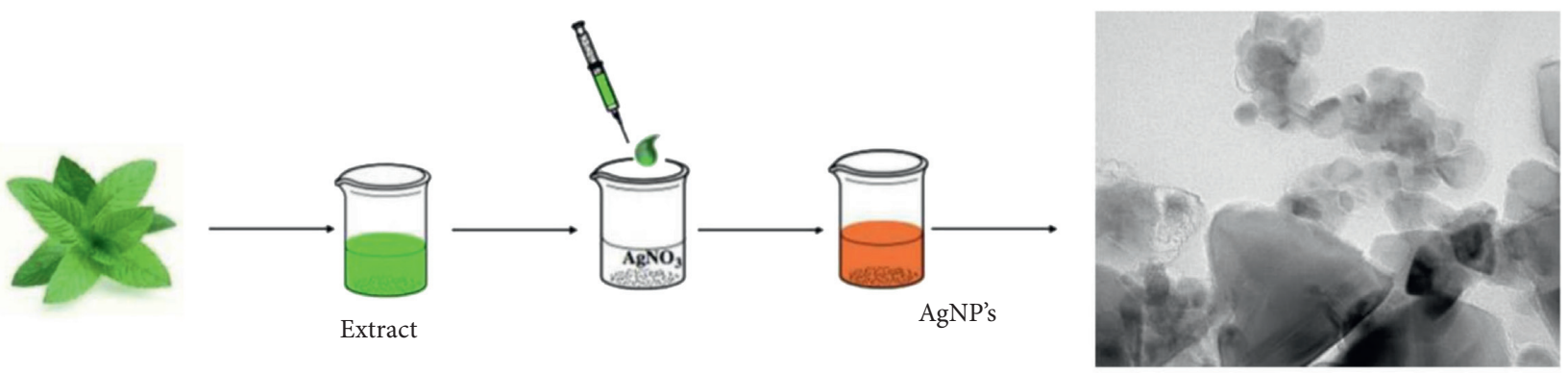

Figure 6: Schematic figure of green synthesis of AgNPs [88]. 
antibacterial efficacy in about 650 bacterial species. Information that silver is less harmful to cells and tissues in nanoparticles further encouraged the usage of AgNPs to medicines and therapeutic uses. A study was performed to assess the synergistic effects of NPs and Aloe vera in root canal disinfection. In endodontic infections, $A$. vera-encapsulated nanomaterials showed durable antibacterial action [42]. Alveolar bone loss, a common condition, makes dental implant placement difficult. A barrier between the bone replacement and the gingiva that prevents fibrotissue ingrowth and bacterial infection and encourages bone development is crucial to alveolar ridge repair. Chen et al. demonstrated how AgNP-coated collagen membranes can help prevent infection after the insertion of bone grafts in alveolar ridge restoration [92].

Multiple studies have suggested their usage in a variety of formulations, with promising results in the treatment of S. mutans, with antibacterial activity 25 times stronger than chlorhexidine, as well as antiviral and antifungal activities [93]. Composite resin is now the most extensively utilized dental material to treat caries lesions, owing to its cosmetic and load-bearing qualities. Microleakage has been seen on composite repair edges, and oral microorganisms can colonize these perforations, resulting in secondary caries. Antimicrobial restorative materials have been created to prevent or reduce biofilm deposition, particularly by integrating AgNPs into composite resins and adhesive systems [94]. Dentures, which are usually made of polymethyl methacrylate (PMMA) acrylic resin, have a rough internal surface, along with other factors (such as poor hygiene and HIV infection), leading to the development of denture stomatitis. Candida species colonize denture surfaces, generating a biofilm that can induce the development of denture stomatitis [95]. Acosta-Torres et al. [63] created PMMA with $1 \mu \mathrm{g} / \mathrm{mL}$ AgNPs and compared it to PMMA that had not been changed. PMMA AgNPs ( $P$ 0.05) specimens revealed reduced C. albicans adhesion than PMMA. Root canal fillings have been made from various materials, with gutta-percha being one of the most popular. Endodontic materials should ideally have some antibacterial action as bacterial removal in root canals is critical to treatment effectiveness. In an attempt to improve the characteristics of gutta-antibacterial percha, Iranian researchers created nanosilver gutta-percha. Gutta-percha coated with AgNPs is efficient against E. faecalis, S. aureus, Candida albicans, and E. coli [96]. Samiei et al. modified mineral trioxide aggregate (MTA) by adding AgNPs at $1 \%$ weight to boost its antibacterial activity. It was tested for its ability to eliminate oral bacteria and fungus. Compared to unmodified MTA, AgNP-containing MTA had a stronger antibacterial activity against $E$. faecalis, Candida albicans, and Pseudomonas aeruginosa [97]. Zhao et al. used silver nitrate immersion and UV radiation to insert AgNPs into titania nanotubes $\left(\mathrm{TiO}_{2}-\mathrm{NTs}\right)$ on $\mathrm{Ti}$ implants. The antibacterial action against $S$. aureus was tested, and the findings showed that planktonic germs were inhibited over the first days. Furthermore, Ti implants coated with AgNPs have shown to be able to inhibit bacteria adherence for up to 30 days, which is regarded enough time to avoid postinfection in the early stages [98].
Rodrigues et al. tested the antibacterial effectiveness including AgNP in an aqueous vehicle, chlorhexidine, and sodium hypochlorite against Enterococcus faecalis biofilm and infected dentinal tubules. The AgNP solution killed fewer bacteria than $\mathrm{NaOCl}$ but could dissolve more biofilm than chlorhexidine. AgNP irrigant was not as effective AgNP against E. faecalis as root canal therapy solutions [99]. Biomaterials containing AgNPs have been developed to prevent or minimize the production of biofilms. They have a unique antibacterial effect without altering the material's mechanical qualities due to their higher surface-to-volume ratio and tiny particle size. AgNPs have a unique feature that allows them to be used as fillers in various biomaterials, where they play an essential role in enhancing the characteristics [100]. These nanoparticles were employed in a twoway dental restorative treatment simultaneously. The use of glass ionomer cement in dentistry has found a significant restriction on poor wear and secondary caries caused by the buildup of bacterial colonies around the restoration when used at an early or aging stage. The produced silver nanoparticles were cemented with glass ionomer cement to meet the two limits. The addition of AgNPs to GIC improves the hardness of traditional GIC and, in turn, eliminates the limiting of secondary caries caused by bacterial colonies around the GIC-fixed restoration in postmedication [44]. Dental equipment and bandages have been made with AgNPs. The addition of AgNPs to orthodontic glue can improve or maintain the glue's shear bond strength while increasing its bacterial resistance [101]. Magalhães et al. found that including AgNPs into dental composites reduced microbial colonization of coating materials, enhancing antifungal capability [102]. Moreover, endodontic fillings containing AgNPs had an antimicrobial action that lasted for a long time against Streptococcus milleri, Staphylococcus aureus, and Enterococcus faecalis [103].

\section{Gold Nanoparticles}

A great deal of research and manufacturing approaches have been used to create gold nanoparticles (AuNPs) by various physical and chemical processes. Due to their unique physicochemical features and a wide variety of uses, numerous publications have been published in recent years on the synthesis and characterization of AuNPs. Physical methods of preparing metallic nanogold (e.g., laser ablation) produce GNPs with a narrow particle size distribution, but they are expensive and yield low. AuNPs can be made chemically (for example, sodium borohydride). Organic solvents' hazardous side effects and the toxic effects of reducing reagents employed in the chemical production of GNPs drew focus to the development of alternative green approaches [104]. AuNPs are a form of nanomaterial that can be readily produced using a one-step environmentally friendly green chemistry process. They are widely known for their biocompatibility and nontoxicity. AuNPs are an excellent contender for biological applications because of their characteristics [17].

Hyperaccumulators are plants that can absorb and collect metals from the water and soil.. Alfalfa may gather 
gold and store it as discrete pure metal nanoparticles in their leaves and stems' biomasses. Various plants, such as broth extracts of neem, Aloe vera, Arena sativa, alfalfa, wheat, geranium, Hibiscus sabdariffa, and lemongrass, have been effectively employed and reported for effective and quick extracellular synthesis of gold, silver, and copper nanoparticles in recent years. It possesses different actions that are ideal for therapeutic usage and broad applications in nanobiotechnology, and it possesses unique nanoscale gold properties [39]. Previous studies on AuNPs have included immune response augmentation, microbe detection, control, cancer cell photothermolysis, clinical chemistry, optical imaging of cancer cells using resonance scattering, targeted drug delivery, two-photon luminescence, and optical coherence tomography. Although AuNPs have the strongest antibacterial activity of all metal NPs, antibiotic-coupled AuNPs have shown the potential for photothermal protozoa and bacteria death. It was demonstrated that AuNPs conjugated with the anticancer drug 5-fluorouracil were more effective against bacteria and fungus than 5-fluorouracil alone. As a result, conjugated NPs can deliver antibiotics to a specific site [6]. AuNPs are suitable for biological applications due to their unique optical features derived from the SPR (surface plasmon resonance) phenomenon and their biocompatibility. AuNPs are shown to have a strong potential for photothermal cancer cell treatment. When AuNPs are subjected to electromagnetic radiation, the resonance of surface-conductive electrons absorbs the radiation in the visible and near-infrared ranges. Cancer cells are thermally degraded via the heat generated.

5.1. Applications in Dentistry. AuNPs have been used to treat gum disorders, dental cavities, tissue engineering, dental implantology, and cancer detection because of their nanostructures, huge surface volume, and biocompatibility. Because AuNPs have antifungal and antibacterial capabilities, they are employed to boost the effect in various biomaterials. They also improve material mechanical properties, resulting in improved results. To illustrate their therapeutic effects, they come in various sizes and concentrations. Because of their properties, AuNPs are a viable candidate for fillers in biomaterials [105].

5.1.1. Dental Caries. AuNPs have a greater surface area because of their nanoscale, allowing for greater inorganic and organic chemical reactions. As a result, AuNPs can be used as a potential anticaries agent. It was discovered that including AuNPs into cavity disinfectants can improve the material's antibacterial activity and, as a result, reduce the risk of secondary caries when compared to conventional treatments [106].

5.1.2. Dental Implants. AuNPs can be used as osteogenic agents for bone regeneration because of their biocompatibility and surface specificity. The osteoinductivity of Salacia chinensis-mediated AuNPs was investigated for usage as a green source osteoinductive biomaterial in implant dentistry by Jadhav et al. Plant-mediated AuNPs produced utilizing green chemistry have been shown to be biocompatible, environmentally friendly nanomolecules that stimulate bone formation and decrease bone resorption and may be utilized as an active bone inductive material during implant placement [55].

5.1.3. Periodontal Disease. Periodontal disease diagnosis is critical for preventing further progression and providing proper treatment. AuNPs play a significant role in diagnosing periodontal disease due to their unique critical optical properties. According to the findings, the size and concentration of AuNPs have a favorable effect on the proliferation of these cells. As a result, AuNPs can be used as a source in tissue engineering to help mend diseased tissues [105].

5.1.4. Stem Cell Technology. Because of their resemblance to a nanostructured environment, nanomaterials have piqued the interest of many tissue engineering experts. These nanomaterials have the ability to infiltrate the nuclei of cells and alter their functions. The effects of AuNPs on stem cells in tissue engineering have been investigated [31]. For the first time, Xia et al. tested the osteogenic induction potential of a new calcium phosphate cement containing AuNP-CPC on human dental pulp stem cells (hDPSCs). AuNPs increased hDPSCs' behavior on CPC, such as cell adhesion and proliferation, as well as osteogenic differentiation (approximately a 2- to 3 -fold increase after 14 days) [107]. Wang concluded that using an eco-friendly, cost-effective, and accessible green synthetic technique, stable, biocompatible, and functional AuNPs may be effectively manufactured. The stability of AuNP colloid solution in vitro was shown to be outstanding in a range of blood components. They discovered that they may be utilized as a pain reliever and an osteoinductive adjuvant in the treatment of dental tissue implantation [54].

5.1.5. Dental Materials. Dadkan et al [108] studied the effect of gold nanofiller particles on microtensile bond strength to dentin in an experimental bonding agent, as well as the optimal filler quantity required to achieve the maximum bond strength. The inclusion of AuNPs increases the flexural and tensile strength of the dental adhesive, with the optimal AuNP concentration resulting in the best mechanical properties. Its flexural and tensile strength optimum concentrations were $10 X$ and $5 X$, respectively. AuNPs can function as a barrier to fracture development in terms of flexural strength, with higher concentrations having a stronger positive impact. At higher concentrations, NPs clump together, which might serve as a good starting point for a fracture [105].

5.1.6. Diagnostic Imaging. Optical imaging is one of the most critical tools in biological research. Bio-optical imaging still has issues with resolution, sensitivity, speed, and penetration depth despite significant advancements. Because of 
their unique optical features, such as surface plasmon resonance, gold nanoparticles (AuNPs) can be easily employed to improve optical imaging through absorption, scattering, fluorescence, Raman scattering, and other means. According to the literature, AuNP-assisted bioimaging is a promising method for probing fundamental biological questions and detecting disorders early [109].

\section{Iron Nanoparticles}

Because of their exceptional physicochemical features, high magnetism, microwave absorption capabilities, low toxicity, and high catalytic activity, iron nanoparticles (INPs) are among the most intriguing new materials. Iron oxide nanoparticles (IONPs) (including magnetite: $\mathrm{Fe}_{3} \mathrm{O}_{4}$, hematite: $-\mathrm{Fe}_{2} \mathrm{O}_{3}$, and maghemite: $-\mathrm{Fe}_{2} \mathrm{O}_{3}$ ), iron oxide-hydroxide $(\mathrm{FeOOH})$ nanoparticles, and zero-valent iron (ZVI) nanoparticles are the three principal categories of INPs [110]. Applications for these particles include delivery of the drug, magnetic targeting, heat exhaustion, heat ablation, stem cell trial and manipulation, gene editing, negative MRI contrast improvement, ferrofluids, preservation of food, bioprocess intensification, antimicrobial agents, environmental remedy, pigments, and lithium-ion batteries [111]. The particles are synthesized using a variety of physical and chemical processes, including the coprecipitation method, sol-gel method, microemulsion method, hydrothermal method, and solvothermal method. The green production of iron nanoparticles is gaining popularity as an environmentally friendly and cost-effective therapeutic method. Afsheen et al. used mango leaves, rose leaves, neem leaves, carom seeds, and clove buds to make iron nanoparticles in a zero-valent oxidation state by an eco-friendly green synthesis at $70^{\circ} \mathrm{C}$ temperature with steady stirring and atmospheric pressure. In combination with a specific proportion of polyvinylpyrrolidone (PVP) instead of polyvinyl alcohol (PVA), different plant extracts play an essential role in the reduction and stabilization of nanoparticles. The significant amount of PVP utilized prevented the particles from agglomerating and oxidizing. The presence of PVP allows particles at the micro-/nanoscale to maintain their crystalline structure after 3 to 4 months of preparation [71]. The primary mechanism of INP generation by plant extracts, including nucleation and particle development, is yet to be found. Phytochemicals (primary and secondary metabolites) in the plant extract, on the contrary, play a critical role in the biosynthesis of INPs, according to research. In fact, phenolic chemicals (polyphenols, flavonoids, tannic acid, and terpenoids) act as natural antioxidants that significantly decrease iron ions to INPs [112]. Artocarpus heterophyllus (jackfruit) peel extract was used to make iron nanoparticles (FeNPs). The peel's strong antioxidant content makes it a potential source of valuable biomolecules that can be used as bioreductants, capping agents, and stabilizing agents in green nanoparticle manufacturing. Apart from employing nontoxic reactant ingredients and being cost-effective, the approach makes use of trash and thereby lowers waste accumulation [113]. Green procedures are the most commonly utilized for the synthesis of INP utilizing the plant-mediated extract of Citrus sinensis since they are both environmentally benign and economically effective. Gram-negative bacteria and Gram-positive bacteria were used to investigate the antibacterial impact of biologically generated IONPs. These findings demonstrated that IONPs have a strong antibacterial potential as they inhibited bacterial strains in a substantial zone [112].

6.1. Applications in Dentistry. Iron oxide nanoparticles (IONPs), such as magnetite and maghemite magnetic nanoparticles, have received a lot of attention in recent years in various sectors. IONPs have been used in biomedicine for a wide range of applications, including diagnosis and treatment. These magnetic nanoparticles can be utilized as contrast in imaging. IONPs can also be employed as nanocarriers for delivering therapeutic drugs to desired cells in vivo due to their magnetic characteristics, low cost, and excellent biocompatibility [114]. Gao et al. described a new technique for controlling biofilms (plaques) based on catalytic nanoparticles (CAT-NPs) comprising biocompatible $\mathrm{Fe}_{3} \mathrm{O}_{4}$ with peroxidase-like activity that promotes extracellular matrix disintegration and bacterial mortality within acidic niches of caries-causing biofilms (Figure 7). They showed that CAT-NP combined with $\mathrm{H}_{2} \mathrm{O}_{2}$ successfully suppresses the onset and severity of dental caries in vivo while protecting normal tissues, using 1-minute topical daily treatments similar to those used in clinical settings [115]. The antibacterial activity of both natural and synthetic medications has been discovered to be improved by the synergy of INP. The action of common natural items against $S$. mutans was examined, including clove buds, neem leaves, and green tea leaves. To compare the effects of various combinations of treatments on $S$. mutans, researchers used the plant extract alone, a plant extract with INP, and the plant extract with INP and amoxicillin. When an antimicrobial agent is coupled with INP, the antimicrobial agent's action is enhanced [74].

\section{Zinc Oxide Nanoparticles}

Zinc is a trace mineral abundantly spread across the body tissue, which contributes to the catalytic activity of several enzymes [116]. Zinc oxide $(\mathrm{ZnO})$ is a biocompatible semiconductor material that is utilized for different purposes to make various dental products such as zinc oxide eugenol, amalgam, ceramics, and dental cements. The Food and Drug Administration considers it to be one of the safest materials in the pharmaceutical industry. The intrinsic features of nanosized $\mathrm{ZnO}$, such as its wide bandgap, high-exciton binding energy, high electronic conductivity, nontoxicity, and chemical durability, have piqued industrial interest. ZnONPs have unique optical features that make them suitable for use as a drug delivery system and anticancer, antibacterial, antidiabetic, and theragnostic tool [117]. Plants are the most popular source of NP synthesis because they allow for large-scale production. Phytochemicals such as polysaccharides, vitamins, amino acids, alkaloids, and terpenoids released by plants are used to reduce metal ions 


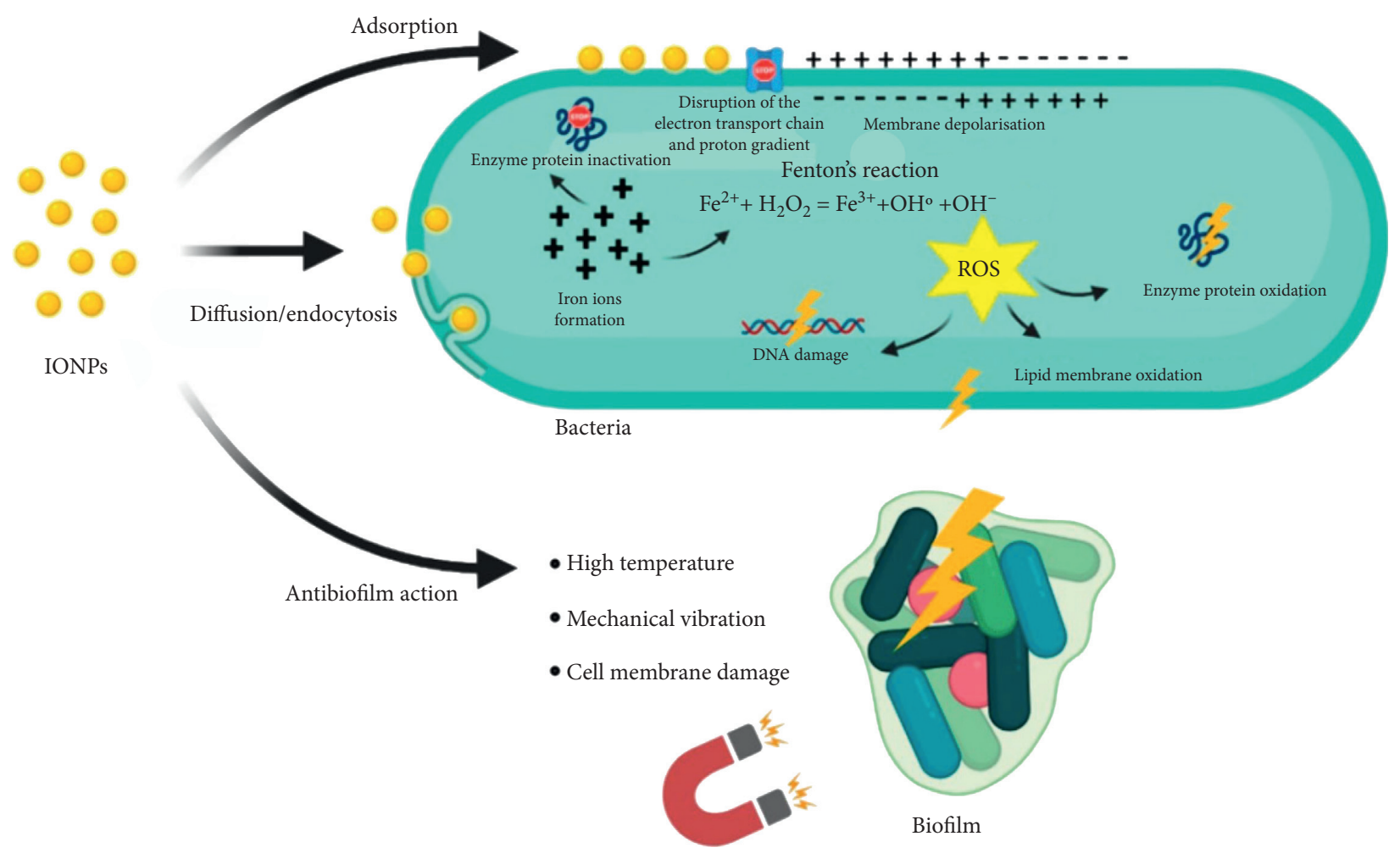

FIgURe 7: Antibacterial and antibiofilm mechanisms of iron oxide nanoparticles [25].

or metal oxides [118]. Plant extracts, such as phenols and flavones, can be used to make ZnONPs. The reducing and capping agents in the extracts, such as phenols and flavones, can stabilize the NPs by electrostatic, steric, hydration, and van der Waals forces. Plant extract-assisted biosynthesis is a reasonably straightforward process that can be completed in three steps. The preparation of the plant extract is usually the initial step. Then, as a precursor, zinc salts are added to plant extracts. Metal ions are reduced into NPs at this stage and then stabilized with reducing and capping agents. After various synthesis procedures such as high-temperature annealing, ZnONPs are created in the last stage [119]. Plants in the Lamiaceae family, including Anisochilus carnosus, Plectranthus amboinicus, and Vitex negundo, have been researched extensively for the NP formation of various sizes and shapes, including spherical, quasi-spherical, hexagonal, rod-shaped, and agglomerates. The size of produced NPs reduces when the content of a plant extract increases, according to the findings [120-122]. The size of CuNP produced from peel was larger, as validated by SEM and TEM studies, but the forms were similar (hexagonal and spherical). Agglomeration was seen in NPs made from extracts of Moringa oleifera, Agathosma betulina, Pongamia pinnata, Plectranthus amboinicus, Nephelium lappaceum, and Calotropis gigantea [123].

7.1. Applications in Dentistry. $\mathrm{Zn}^{2+}$ ions disrupt bacterial enzyme systems by displacing magnesium ions required for dental plaque enzymatic activity. Tavassoli Hojati et al. [21] demonstrated that including $\mathrm{ZnONPs}$ into resin composites may considerably inhibit $S$. mutans strains without losing the resin's mechanical qualities. Another explanation could be due to electrostatic forces induced by light exposure, resulting in interactions between the nanoparticles and bacteria [124] (Figure 8). On Streptococcus mutans, the antibacterial effect of composite resin containing ZnONPs was much higher than that of composite resin containing AgNPs [126]. Implant failure is frequently caused by infections linked with the prosthesis and aseptic loosening. Improved antibacterial properties and osseointegration of orthopedic implants are critical. Zinc oxide nanoparticles (ZnONPs) are a form of zinc-containing metal oxide nanoparticle that has been extensively explored in a variety of sectors, including food packaging, pollution control, and biomedicine. Low toxicity and good biological functions, as well as antibacterial, anticancer, and osteogenic properties, characterize ZnONPs. Furthermore, $\mathrm{ZnONPs}$ may be made readily using a variety of ways. Green preparation approaches, for example, can improve the bioactivity of ZnONPs and increase their biological application potential [119]. Implants with ZnONP modifications have good antibacterial characteristics. Elizabeth et al. covered titania nanotubes and titania nanoleaves with ZnONPs. The antibacterial capabilities of modified samples were dramatically improved compared to pure nanopatterned materials [127]. By electrospinning polyetherimide (PEI) with various concentrations of $\mathrm{ZnONPs}$, Artifon et al. were able to create a variety of $\mathrm{ZnO} / \mathrm{PEI}$ scaffolds. The antibacterial action was more vital as the ZnONP level rose. ZnNP-modified implants can modulate the immune system and increase antibacterial characteristics, in addition to direct toxicity against microorganisms [128]. 


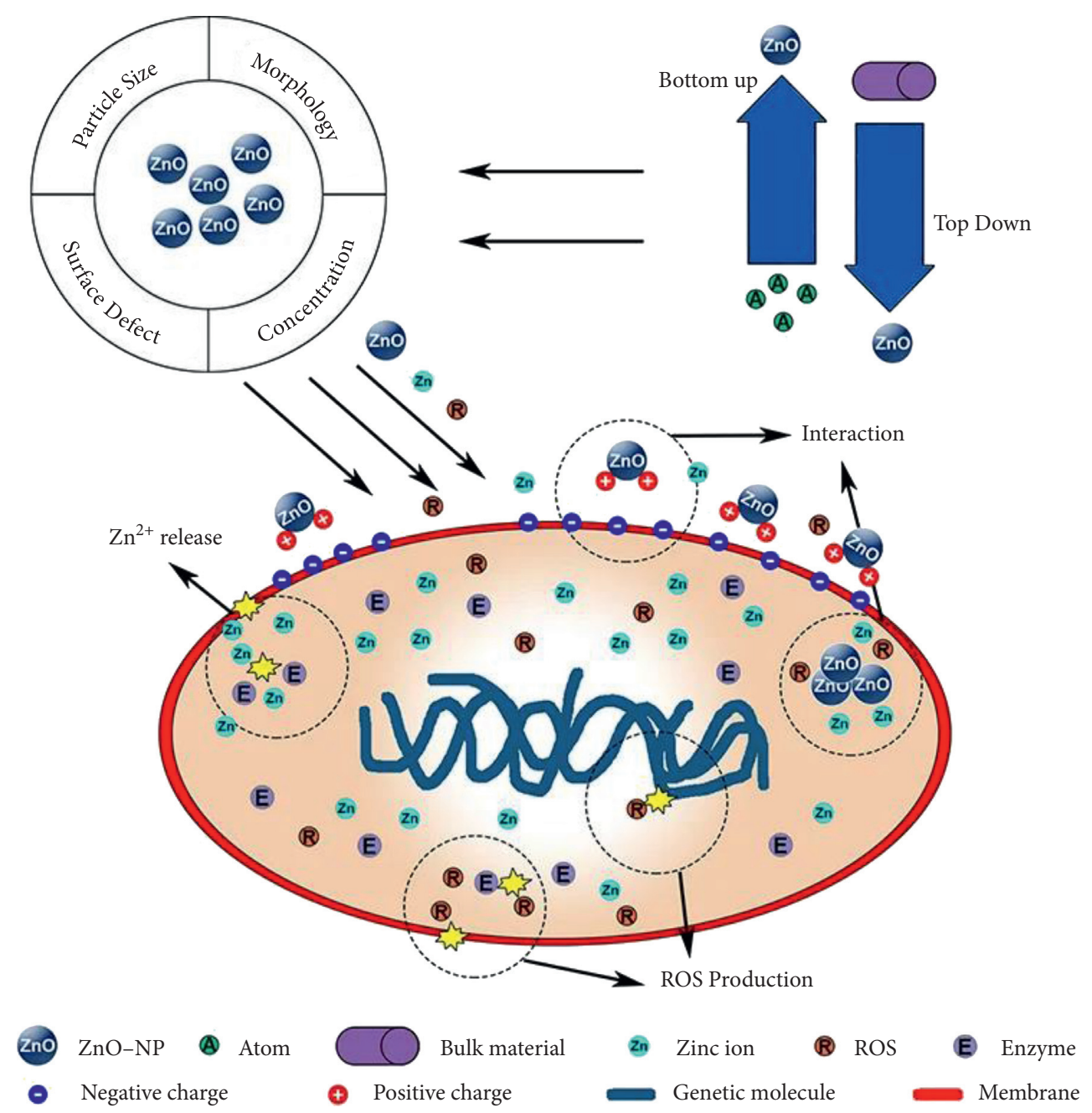

Figure 8: Antibacterial mechanism of ZnNPs [125].

\section{Titanium Oxide Nanoparticles}

The entire biosynthetic process begins with mixing a simple precursor salt with the biological extract; the extract's metabolites can then reduce and stabilize the bulk metal into an elemental form through a series of mechanical stages. This biosynthetic approach has several advantages over chemical and physical procedures, and it has emerged as a simple, safe, and viable alternative. Aside from this, biological approaches can efficiently catalyze the synthesis process at any size and under any condition. Furthermore, NPs of controlled size and form can be made. Because of these advantages, several researchers have planned to investigate various species for their ability to manufacture $\mathrm{TiO}_{2}$ NPs [129]. Forming a solution of a titanium precursor with the required solvent is the most common way to make $\mathrm{TiO}_{2}$ nanoparticles. Ethanol and distilled water are the most commonly utilized solvents for this purpose. TTIP (titanium tetraisopropoxide), $\mathrm{TiCl}_{4}$ (titanium tetrachloride), and $\mathrm{TiO}(\mathrm{OH})_{2}$ are common titanium precursors used to greenly produce $\mathrm{TiO}_{2}$ nanoparticles (metatitanic acid or titanyl hydroxide). The synthesis procedures also use $\mathrm{TiOSO}_{4}$ (titanium oxysulfate) and $\mathrm{TiO}_{2}$ bulk particles; in fact, this is one of the advantages of green nanotechnology: water-soluble precursors can be used equally [130]. Plant components such as phenolic acids, alkaloids, proteins, enzymes, and carbohydrates govern the synthesis of NPs through reduction and stabilization mechanisms. To produce diverse forms of $\mathrm{TiO}_{2} \mathrm{NPs}$, a variety of plant species have been employed. When a precursor $\mathrm{TiO}_{2}$ salt is tainted with the plant extract, the reaction mixes heat up quickly. Then, the solution is constantly stirred at a moderate temperature. The initial synthesis indicator is a color change, which can be validated later using spectroscopic techniques. Several color indicators have been recorded in the production of $\mathrm{TiO}_{2} \mathrm{NPs}$, ranging from pale green to dark green [77]. The nanoparticles are then filtered, rinsed with distilled water, dried, and calcined. To eliminate organic groups, calcination is usually carried out at temperatures ranging from 400 to $800^{\circ} \mathrm{C}$ [130]. Ahmad et al. studied the antibacterial and antifungal properties of greenproduced titanium dioxide $\left(\mathrm{TiO}_{2}\right)$ nanoparticles utilizing Mentha arvensis leaf extract as the reducing agent and titanium tetraisopropoxide as the precursor. Green $\mathrm{TiO}_{2}$ nanoparticles showed promising antibacterial and antifungal action against various microorganisms [131]. $\mathrm{TiO}_{2}$ nanoparticles (NPs) were green-synthesized using the 
extracts of Azadirachta indica twigs, Ficus benghalensis, Syzygium aromaticum, Mentha arvensis, Citrus aurantifolia, Echinacea purpurea, and Acanthophyllum laxiusculum [75-77, 131].

8.1. Applications in Dentistry. Titanium dioxide nanoparticles $\left(\mathrm{TiO}_{2} \mathrm{NPs}\right)$ are valuable additions in adhesives and composites because of their photocatalytic, antimicrobial, and UV-absorbing capabilities. However, the ROS created by photoactivated $\mathrm{TiO}_{2}$ NPs has been linked to toxicological concerns. Sun et al. revealed that acid-functionalized $\mathrm{TiO}_{2}$ NPs might be incorporated into dental resins that can be used as dental adhesives on human teeth. The ROS produced by these NPs when exposed to visible light can be used to boost the degree of vinyl conversion in resins, resulting in adhesives with improved shear bond strength to human teeth. The genotoxicity of the NPs and their potential for release from dental composites were investigated, and the results showed that there was a low danger of genotoxic effects [132]. When the mechanical properties of the composites were evaluated, it was discovered that using $\mathrm{TiO}_{2}$ as a reinforcing agent strengthened the polymer. The morphological observation revealed substantial adhesion between $\mathrm{TiO}_{2}$ and the polymer matrices, as well as a uniform distribution of $\mathrm{TiO}_{2}$ within the polymer matrix. The mechanical properties of $\mathrm{TiO}_{2}$ were improved by adequate compatibilization with the polymer matrix [133]. Titanium dioxide is an inorganic chemical that has recently received a lot of attention due to its photoactivity. $\mathrm{TiO}_{2}$ produces a variety of ROS after being exposed to UV radiation in aqueous solutions. The capacity to produce ROS and consequently induce cell death has been used in photodynamic therapy (PDT) to treat a variety of ailments ranging from psoriasis to cancer. $\mathrm{TiO}_{2}$ NPs have been investigated as photosensitizing agents for treating malignant tumors and photodynamic inactivation of antibiotic-resistant microorganisms. In PDT, $\mathrm{TiO}_{2}$ NPs can be employed as photosensitizers on their own, as well as in composites and mixtures with other chemicals or biomolecules. Furthermore, different chemical molecules can be grafted onto $\mathrm{TiO}_{2}$ nanoparticles to create hybrid materials. These nanostructures can show higher light absorption, allowing them to be used in medicine for focused therapy. Many titanium dioxide-based techniques were tested to improve the efficacy of anticancer and antibacterial medicines [134]. The extracts of Azadirachta indica twigs, Ficus benghalensis, and Syzygium aromaticum were used to make $\mathrm{TiO}_{2}$ nanoparticles (NPs). G-TiO 2 NPs were investigated for antibacterial and antibiofilm properties against bacteria (Streptococcus mutans and Citrobacter freundii) and fungus (Candida albicans). According to this study, greenly produced $\mathrm{TiO}_{2}$ NPs have outstanding antibacterial and antibiofilm characteristics [75].

\section{Copper Nanoparticles}

Copper nanoparticles (CuNPs) have garnered attention in the recent two decades because of their simple nature and the property of demonstrating a range of potentially beneficial physical properties depending on their size, shape, and composition. Natural plants have free radical scavengers that help prevent diseases including heart disease, cancer, arthritis, and liver disease and effectively reduce oxidative damage. Vital water in copper containers cleans water by killing bacteria species and strains and effectively eliminates bacteria, making it bactericidal. Furthermore, compared to other antibacterial agents such as gold and silver, copper is a less expensive option. Compared to other organic antibacterial agents, it exhibits antioxidant capabilities and longer shelf life. They have these unique physical, chemical, and biological features because of their highly distinctive crystal shape and high surface areavolume ratio [62]. Copper nanoparticles were created using both physical and chemical methods. The microemulsion technique is the most prevalent chemical strategy, although it is expensive and requires a high surfactant concentration. Physical methods for synthesizing nanoparticles include laser ablation, aerosol techniques, and radiolysis. However, these methods are less popular because of the high cost of instruments and high energy consumption. In the absence of a stabilizing agent, copper nanoparticles can be made via microwave irradiation. The inclusion of ascorbic acid during the synthesis of copper oxide results in the formation of nanoparticles. Because of their availability, cost-effectiveness, environmental friendliness, and lack of harmful byproducts, plants have been employed to synthesize metallic nanoparticles [135]. Mixing a known concentration of the plant extract with a known precursor concentration and heating the mixture to a defined temperature with continuous stirring at a set period is one of the most popular methods for generating $\mathrm{Cu}$ and $\mathrm{CuO}$ NPs (Figure 9) [136]. The medical qualities of the plant extract are seen to protect the NPs generated from it, which could be used in medicine, targeted drug delivery, and cosmetic applications. CuNPs have also gained interest due to their potential industrial applications, such as gas sensors, catalytic processes, high-temperature superconductors, and solar cells, as well as their applications in wound dressings and biocidal qualities. Antibiotics use CuNPs because of their remarkable physical characteristics. They are used as a bactericidal agent to coat medical equipment, such as heat transfer systems, antimicrobial materials, superstrong materials, sensors, and catalysts, due to their disinfecting characteristics and matrix stability. The bactericidal impact of NPs has been improved because of their tiny size [137]. CuNP has been synthesized using extracts of various plants such as Celastrus paniculatus, Cardiospermum halicacabum, Zingiber officinale, Eryngium caucasicum, Plectranthus amboinicus, Azadirachta indica, Punica granatum, Eclipta prostrata, Citrus medica Linn., and Madhuca longifolia [28, 60-62, 64-69].

9.1. Applications in Dentistry. Unlike silver, ions' release is not the most critical factor in copper nanoparticles' bactericidal activity. Other parameters, such as the nanoparticles' oxidation state, size, and crystalline structure, significantly impact the process. CuNPs' bactericidal action against Aggregatibacter actinomycetemcomitans (one of the principal pathogens responsible for producing localized aggressive periodontitis) and cytocompatibility make them a good candidate for use as an 


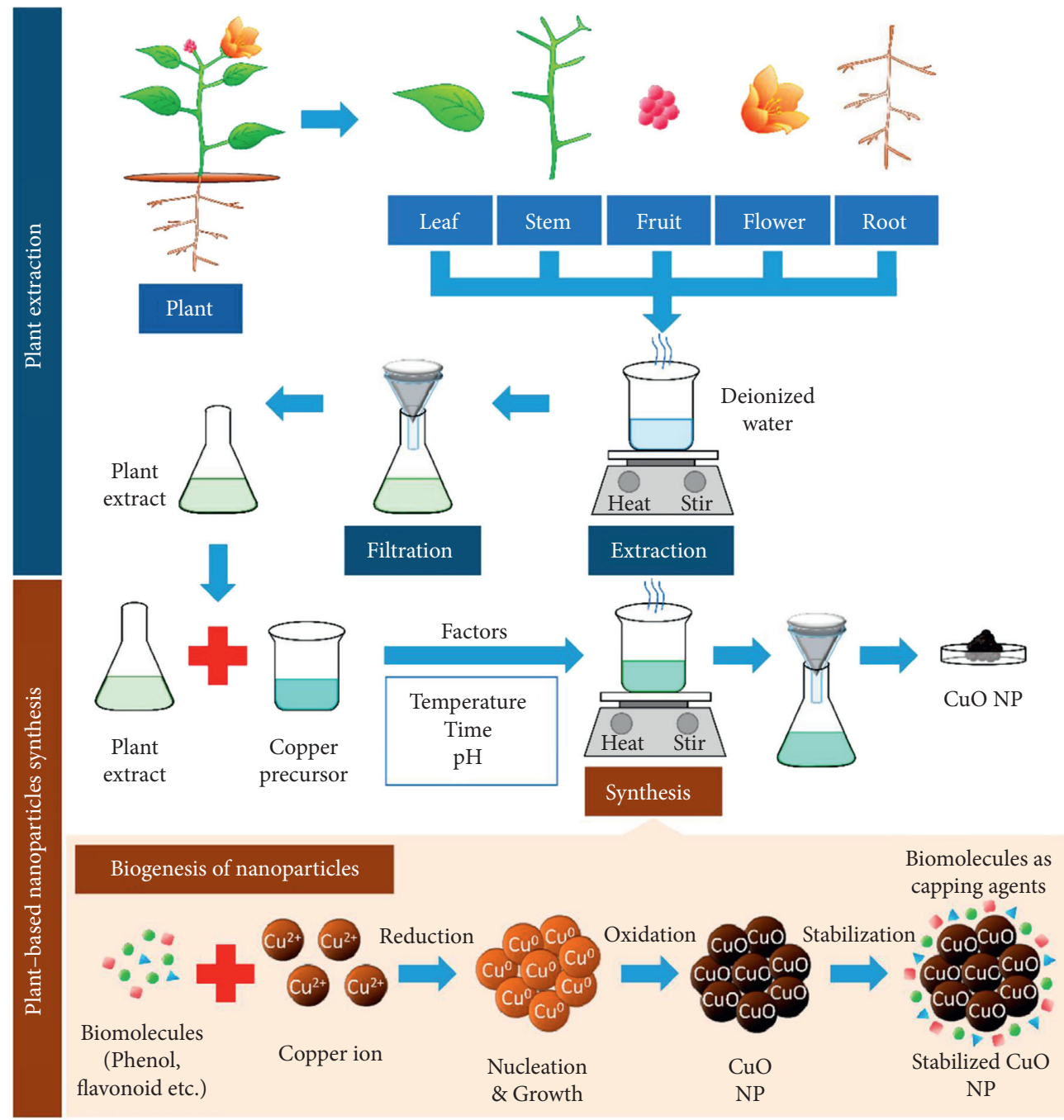

FIGURE 9: Plant-based green synthesis of copper oxide nanoparticles [136].

anti-peri-implantitis agent in oral implants [138]. Copper oxide nanoparticles made from Aloe vera gel have been found to have excellent anticariogenic properties and can be used in a variety of dental applications [36]. To prevent and minimize the occurrence of secondary caries, glass ionomer cements (GICs) with an excellent fluoride-ion releasing function have been used. The antibacterial characteristics of the copper-doped glass ionomer-based materials were dramatically increased, and collagen degradation was significantly reduced. The use of copper-doped glass ionomer-based materials for composite restore may assist them to live longer because of its increased antibacterial capacities and decayed collagen breakdown [139]. CuNP applied to adhesives at a concentration of up to $0.5 \mathrm{wt} \%$ can offer antibacterial properties and prevent adhesive interface degradation without affecting the formulation's mechanical capabilities, according to Gutiérrez et al. [140].

\section{Future Prospects}

Herbal medication, nanometer-sized, has a bright future in enhancing biological activity and overcoming the issues associated with chemical/synthetic pharmaceuticals. As a result, the use of green pharmaceuticals in nanodrug delivery systems improves the usage of herbal plants and aids in treating numerous ailments. Plant nanoparticles can be used to a greater extent to prevent oral diseases, dentures, and implants, oral cancer prevention and treatment, and oral health care. Furthermore, substantial research on the numerous chemicals found in herbal remedies, as well as their subsequent nanoparticle manufacturing, should be done. Herbal nanomedicine technologies must be thoroughly investigated for efficacy and application in dentistry. In vivo testing should be done on all plant nanoparticles that demonstrate anticancer potential in diverse malignancies. Plant nanoparticles with antioxidant properties should also be tested for a variety of dental uses.

\section{Conclusion}

Since ancient times, herbal medicine has been utilized to treat oral/dental diseases and provide everyday care. Plantmediated biogenic metal nanoparticles can overcome the drawbacks of herbal treatments, making the development of herbal medicine-incorporated nanoparticle formulations in 
dentistry a novel breakthrough. The use of medicinal plant extracts in the green production of metal nanoparticles such as silver, copper, and gold nanoparticles has been shown to be effective in treating a variety of oral/dental diseases, even outperforming conventional materials. These are also found in toothpaste and mouthwash, as well as other dental care products. However, there is a lack of knowledge about the safety of nanomaterials, necessitating more research. Many concerns, including medication resistance, could be addressed using nanoparticles and a combination of plant extracts. Herbal medicines are a suitable option for allopathic drugs in dentistry since they lessen the adverse effects of chemicals and antibiotics. Therefore, herbal extracts are precious in dental care because of their safety, naturalness, and cost-effectiveness. In this instance, educating people about the advantages of utilizing herbal treatments to avoid oral diseases will be quite valuable. Nanotechnology is expected to be used in all dental applications because it effectively addresses herbal medicine's limitations such as low oral absorption, low water solubility, poor bioavailability, physical instability, and slow and toxic pharmacological actions.

\section{Ethical Approval}

This article is a review and does not contain any studies with humans or animals performed by the authors.

\section{Conflicts of Interest}

The authors declare that they have no conflicts of interest.

\section{Acknowledgments}

The authors would like to acknowledge colleagues who gave valuable comments.

\section{References}

[1] W. Song and S. Ge, "Application of antimicrobial nanoparticles in dentistry," Molecules, vol. 24, no. 6, Article ID 1033, 2019.

[2] H. B. Ahmed, M. A. Attia, F. M. S. E. El-Dars, and H. E. Emam, "Hydroxyethyl cellulose for spontaneous synthesis of antipathogenic nanostructures: (Ag \& $\mathrm{Au}$ ) nanoparticles versus $\mathrm{Ag}-\mathrm{Au}$ nano-alloy," International Journal of Biological Macromolecules, vol. 128, pp. 214-229, 2019.

[3] H. B. Ahmed, N. Saad, and H. E. Emam, "Recyclable palladium based nano-catalytic laborer encaged within biogranules for dye degradation," Surfaces and Interfaces, vol. 25, Article ID 101175, 2021.

[4] H. E. Emam and H. B. Ahmed, "Carboxymethyl cellulose macromolecules as generator of anisotropic nanogold for catalytic performance," International Journal of Biological Macromolecules, vol. 111, pp. 999-1009, 2018.

[5] H. E. Emam, M. K. Zahran, and H. B. Ahmed, "Generation of biocompatible nanogold using $\mathrm{H}_{2} \mathrm{O}_{2}$-starch and their catalytic/antimicrobial activities," European Polymer Journal, vol. 90, pp. 354-367, 2017.

[6] R. Emmanuel, M. Saravanan, M. Ovais, S. Padmavathy, Z. K. Shinwari, and P. Prakash, "Antimicrobial efficacy of drug blended biosynthesized colloidal gold nanoparticles from Justicia glauca against oral pathogens: a nanoantibiotic approach," Microbial Pathogenesis, vol. 113, pp. 295-302, 2017.

[7] J. A. Souza, D. B. Barbosa, A. A. Berretta et al., "Green synthesis of silver nanoparticles combined to calcium glycerophosphate: antimicrobial and antibiofilm activities," Future Microbiology, vol. 13, no. 3, pp. 345-357, 2018.

[8] R. M. Abdelhameed, M. El-Shahat, and H. E. Emam, "Employable metal (Ag \& Pd)@MIL-125-NH2@cellulose acetate film for visible-light driven photocatalysis for reduction of nitro-aromatics," Carbohydrate Polymers, vol. 247, Article ID 116695, 2020.

[9] H. B. Ahmed and H. E. Emam, "Seeded growth core-shell $(\mathrm{Ag}-\mathrm{Au}-\mathrm{Pd})$ ternary nanostructure at room temperature for potential water treatment," Polymer Testing, vol. 89, Article ID 106720, 2020.

[10] A. Rónavári, N. Igaz, D. I. Adamecz et al., "Green silver and gold nanoparticles: biological synthesis approaches and potentials for biomedical applications," Molecules, vol. 26, no. 4, Article ID 844, 2021.

[11] G. L. Fernandes, A. C. B. Delbem, J. G. Do Amaral et al., "Nanosynthesis of silver-calcium glycerophosphate: promising association against oral pathogens," Antibiotics, vol. 7, no. 3, Article ID 52, 2018.

[12] H. E. Emam, H. B. Ahmed, and R. M. Abdelhameed, "Melt intercalation technique for synthesis of hetero-metallic@ chitin bio-composite as recyclable catalyst for prothiofos hydrolysis," Carbohydrate Polymers, vol. 266, Article ID 118163, 2021.

[13] H. E. Emam, M. A. Attia, F. M. S. E. El-Dars, and H. B. Ahmed, "Emerging use of homogenic and heterogenic nano-colloids synthesized via size-controllable technique in catalytic potency," Journal of Polymers and the Environment, vol. 28, no. 2, pp. 553-565, 2020.

[14] F. Carrouel, S. Viennot, L. Ottolenghi, C. Gaillard, and D. Bourgeois, "Nanoparticles as anti-microbial, anti-inflammatory, and remineralizing agents in oral care cosmetics: a review of the current situation," Nanomaterials, vol. 10, no. 1, Article ID 140, 2020.

[15] M. Ayaz, M. Junaid, F. Ullah et al., "Chemical profiling, antimicrobial and insecticidal evaluations of Polygonum hydropiper L," BMC Complementary and Alternative Medicine, vol. 16, no. 1, Article ID 502, 2016.

[16] Y. N. Slavin, J. Asnis, U. O. Häfeli, and H. Bach, "Metal nanoparticles: understanding the mechanisms behind antibacterial activity," Journal of Nanobiotechnology, vol. 15, no. 1, pp. 65-20, 2017.

[17] M. Yadi, E. Mostafavi, B. Saleh et al., "Current developments in green synthesis of metallic nanoparticles using plant extracts: a review," Artificial cells, nanomedicine, and biotechnology, vol. 46, no. 3, pp. S336-S43, 2018.

[18] C. Minelli, "Measuring nanoparticle properties: are we high and dry or all at sea?" in Proceedings of the Nanoparticle Characterisation-Challenges for the Community'event-IOP Institute of Physics, Book of Abstracts, London, UK, July 2016.

[19] H. B. Ahmed, M. M. Mikhail, S. El-Sherbiny, K. S. Nagy, and H. E. Emam, "pH responsive intelligent nano-engineer of nanostructures applicable for discoloration of reactive dyes," Journal of Colloid and Interface Science, vol. 561, pp. 147-161, 2020.

[20] H. E. Emam, N. M. Saad, A. E. M. Abdallah, and H. B. Ahmed, "Acacia gum versus pectin in fabrication of catalytically active palladium nanoparticles for dye 
discoloration," International Journal of Biological Macromolecules, vol. 156, pp. 829-840, 2020.

[21] S. Tavassoli Hojati, H. Alaghemand, F. Hamze et al., "Antibacterial, physical and mechanical properties of flowable resin composites containing zinc oxide nanoparticles," Dental Materials, vol. 29, no. 5, pp. 495-505, 2013.

[22] S. R. Falsafi, H. Rostamabadi, E. Assadpour, and S. M. Jafari, "Morphology and microstructural analysis of bioactiveloaded micro/nanocarriers via microscopy techniques; CLSM/SEM/TEM/AFM," Advances in Colloid and Interface Science, vol. 280, Article ID 102166, 2020.

[23] S. Mourdikoudis, R. M. Pallares, and N. T. K. Thanh, "Characterization techniques for nanoparticles: comparison and complementarity upon studying nanoparticle properties," Nanoscale, vol. 10, no. 27, pp. 12871-12934, 2018.

[24] K. Ashizawa, "Nanosize particle analysis by dynamic light scattering (DLS)," Yakugaku Zasshi, vol. 139, no. 2, pp. 237-248, 2019.

[25] S. V. Gudkov, D. E. Burmistrov, D. A. Serov, M. B. Rebezov, A. A. Semenova, and A. B. Lisitsyn, "Do iron oxide nanoparticles have significant antibacterial properties?" Antibiotics, vol. 10, no. 7, Article ID 884, 2021.

[26] E. Sánchez-López, D. Gomes, G. Esteruelas et al., "Metalbased nanoparticles as antimicrobial agents: an overview," Nanomaterials, vol. 10, no. 2, Article ID 292, 2020.

[27] R. Singh and J. W. Lillard, "Nanoparticle-based targeted drug delivery," Experimental and Molecular Pathology, vol. 86, no. 3, pp. 215-223, 2009.

[28] I. M. Chung, A. Abdul Rahuman, S. Marimuthu et al., "Green synthesis of copper nanoparticles using Eclipta prostrata leaves extract and their antioxidant and cytotoxic activities," Experimental and Therapeutic Medicine, vol. 14, no. 1, pp. 18-24, 2017.

[29] S. Ahmed, M. Ahmad, B. L. Swami, and S. Ikram, "A review on plants extract mediated synthesis of silver nanoparticles for antimicrobial applications: a green expertise," Journal of Advanced Research, vol. 7, no. 1, pp. 17-28, 2016.

[30] X. F. Zhang, Z. G. Liu, W. Shen, and S. Gurunathan, "Silver nanoparticles: synthesis, characterization, properties, applications, and therapeutic approaches," International Journal of Molecular Sciences, vol. 17, no. 9, Article ID 1534, 2016.

[31] P. Mathur, S. Jha, S. Ramteke, and N. K. Jain, "Pharmaceutical aspects of silver nanoparticles," Artificial cells, nanomedicine, and biotechnology, vol. 46, no. 1, pp. 115-126, 2018.

[32] I. Hussain, N. B. Singh, A. Singh, H. Singh, and S. C. Singh, "Green synthesis of nanoparticles and its potential application," Biotechnology Letters, vol. 38, no. 4, pp. 545-560, 2016.

[33] A. Gour and N. K. Jain, "Advances in green synthesis of nanoparticles," Artificial cells, nanomedicine, and biotechnology, vol. 47, no. 1, pp. 844-851, 2019.

[34] M. M. Al-Ansari, N. D. Al-Dahmash, and A. J. A. Ranjitsingh, "Synthesis of silver nanoparticles using gum Arabic: evaluation of its inhibitory action on Streptococcus mutans causing dental caries and endocarditis," Journal of Infection and Public Health, vol. 14, no. 3, pp. 324-330, 2021.

[35] M. C. Rodrigues, W. R. Rolim, M. M. Viana et al., "Biogenic synthesis and antimicrobial activity of silica-coated silver nanoparticles for esthetic dental applications," Journal of Dentistry, vol. 96, Article ID 103327, 2020.

[36] S. Rajeshkumar, M. Tharani, M. Jeevitha, and J. Santhoshkumar, "Anticariogenic activity of fresh Aloe vera gel mediated copper oxide nanoparticles," Indian Journal of Public Health Research \& Development, vol. 10, no. 11, 2019.

[37] A. Kumar, R. Majumdar, and T. Dhewa, "In vitro efficacy of biosynthesized AgNPs against Streptococcus mutans causing dental plaque formation," Journal of Scientific and Industrial Research, vol. 77, no. 4, 2018.

[38] R. Thomas, S. Snigdha, K. B. Bhavitha, S. Babu, A. Ajith, and E. K. Radhakrishnan, "Biofabricated silver nanoparticles incorporated polymethyl methacrylate as a dental adhesive material with antibacterial and antibiofilm activity against Streptococcus mutans," 3 Biotech, vol. 8, no. 9, Article ID 404, 2018.

[39] R. Teimuri-Mofrad, R. Hadi, B. Tahmasebi, S. Farhoudian, M. Mehravar, and R. Nasiri, "Green synthesis of gold nanoparticles using plant extract: mini-review," Nanochemistry Research, vol. 2, no. 1, pp. 8-19, 2017.

[40] T. Suwan, S. Khongkhunthian, and S. Okonogi, "Green synthesis and inhibitory effects against oral pathogens of silver nanoparticles mediated by rice extracts," Drug Discoveries \& Therapeutics, vol. 12, no. 4, pp. 189-196, 2018.

[41] V. Manikandan, P. Velmurugan, J. H. Park et al., "Green synthesis of silver oxide nanoparticles and its antibacterial activity against dental pathogens," 3 Biotech, vol. 7, no. 1, Article ID 72, 2017.

[42] S. Haripriya and P. Ajitha, "Antimicrobial efficacy of silver nanoparticles of Aloe vera," Journal of Advanced Pharmacy Education \& Research, vol. 7, no. 2, 2017.

[43] V. Velu, M. Das, A. N. Raj N, K. Dua, and H. Malipeddi, "Evaluation of in vitro and in vivo anti-urolithiatic activity of silver nanoparticles containing aqueous leaf extract of Tragia involucrata," Drug delivery and translational research, vol. 7, no. 3, pp. 439-449, 2017.

[44] D. Sundeep, T. Vijaya Kumar, P. S. S. Rao, R. V. S. S. N. Ravikumar, and A. Gopala Krishna, "Green synthesis and characterization of Ag nanoparticles from Mangifera indica leaves for dental restoration and antibacterial applications," Progress in Biomaterials, vol. 6, no. 1, pp. 57-66, 2017.

[45] A. Saravanakumar, M. M. Peng, M. Ganesh, J. Jayaprakash, M. Mohankumar, and H. T. Jang, "Low-cost and eco-friendly green synthesis of silver nanoparticles using Prunus japonica (Rosaceae) leaf extract and their antibacterial, antioxidant properties," Artificial cells, nanomedicine, and biotechnology, vol. 45, no. 6, pp. 1165-1171, 2017.

[46] S. J. P. Jacob, V. L. S. Prasad, S. Sivasankar, and P. Muralidharan, "Biosynthesis of silver nanoparticles using dried fruit extract of Ficus carica-screening for its anticancer activity and toxicity in animal models," Food and Chemical Toxicology, vol. 109, no. 2, pp. 951-956, 2017.

[47] K. Shanker, G. K. Mohan, M. A. Hussain, N. Jayarambabu, and P. L. Pravallika, "Green biosynthesis, characterization, in vitro antidiabetic activity, and investigational acute toxicity studies of some herbal-mediated silver nanoparticles on animal models," Pharmacognosy Magazine, vol. 13, no. 49, pp. 188-192, 2017.

[48] S. Ahmed, Saifullah, M. Ahmad, B. L. Swami, and S. Ikram, "Green synthesis of silver nanoparticles using Azadirachta indica aqueous leaf extract," Journal of radiation research and applied sciences, vol. 9, no. 1, pp. 1-7, 2016.

[49] D. Nayak, S. Ashe, P. R. Rauta, M. Kumari, and B. Nayak, "Bark extract mediated green synthesis of silver nanoparticles: evaluation of antimicrobial activity and antiproliferative response against osteosarcoma," Materials Science and Engineering: C, vol. 58, pp. 44-52, 2016. 
[50] S. Majeed and M. Khanday, "Green synthesis of silver nanoparticles using bark extract of salix alba and its antimicrobial effect against bacteria isolated from dental plaque," Oriental Journal of Chemistry, vol. 32, no. 3, Article ID 1611, 2016.

[51] P. S. Ramesh, T. Kokila, and D. Geetha, "Plant mediated green synthesis and antibacterial activity of silver nanoparticles using Emblica officinalis fruit extract," Spectrochimica Acta Part A: Molecular and Biomolecular Spectroscopy, vol. 142, pp. 339-343, 2015.

[52] R. Emmanuel, S. Palanisamy, S.-M. Chen et al., "Antimicrobial efficacy of green synthesized drug blended silver nanoparticles against dental caries and periodontal disease causing microorganisms," Materials Science and Engineering: C, vol. 56, pp. 374-379, 2015.

[53] S. M. Pourmortazavi, M. Taghdiri, V. Makari, and M. Rahimi-Nasrabadi, "Procedure optimization for green synthesis of silver nanoparticles by aqueous extract of Eucalyptus oleosa," Spectrochimica Acta Part A: Molecular and Biomolecular Spectroscopy, vol. 136, pp. 1249-1254, 2015.

[54] M. Wang and L. Wang, "Plant polyphenols mediated synthesis of gold nanoparticles for pain management in nursing care for dental tissue implantation applications," Journal of Drug Delivery Science and Technology, vol. 58, Article ID 101753, 2020.

[55] K. Jadhav, R. Hr, S. Deshpande et al., "Phytosynthesis of gold nanoparticles: characterization, biocompatibility, and evaluation of its osteoinductive potential for application in implant dentistry," Materials Science and Engineering: C, vol. 93, pp. 664-670, 2018.

[56] R. Vijayan, S. Joseph, and B. Mathew, "Indigofera tinctoria leaf extract mediated green synthesis of silver and gold nanoparticles and assessment of their anticancer, antimicrobial, antioxidant and catalytic properties," Artificial cells, nanomedicine, and biotechnology, vol. 46, no. 4, pp. 861-871, 2018.

[57] A. Bhattacherjee, T. Ghosh, and A. Datta, "Green synthesis and characterisation of antioxidant-tagged gold nanoparticle (X-GNP) and studies on its potent antimicrobial activity," Journal of Experimental Nanoscience, vol. 13, no. 1, pp. 50-61, 2018.

[58] P. Singh, Y. J. Kim, C. Wang, R. Mathiyalagan, and D. C. Yang, "The development of a green approach for the biosynthesis of silver and gold nanoparticles by using Panax ginseng root extract, and their biological applications," Artificial cells, nanomedicine, and biotechnology, vol. 44, no. 4, pp. 1150-1157, 2016.

[59] B. Sadeghi, M. Mohammadzadeh, and B. Babakhani, "Green synthesis of gold nanoparticles using Stevia rebaudiana leaf extracts: characterization and their stability," Journal of Photochemistry and Photobiology B: Biology, vol. 148, pp. 101-106, 2015.

[60] S. C. Mali, A. Dhaka, C. K. Githala, and R. Trivedi, "Green synthesis of copper nanoparticles using Celastrus paniculatus Willd. leaf extract and their photocatalytic and antifungal properties," Biotechnology Reports, vol. 27, Article ID e00518, 2020.

[61] P. Punniyakotti, P. Panneerselvam, D. Perumal, R. Aruliah, and S. Angaiah, "Anti-bacterial and anti-biofilm properties of green synthesized copper nanoparticles from Cardiospermum halicacabum leaf extract," Bioprocess and Biosystems Engineering, vol. 43, pp. 1649-1657, 2020.

[62] R. S. Devi, M. Jeevitha, S. Preetha, and S. Rajeshkumar, "Free radical scavenging activity of copper nanoparticles synthesized from dried ginger," Journal of Pharmaceutical Research International, vol. 32, pp. 1-7, 2020.

[63] L. S. Acosta-Torres, I. Mendieta, R. E. Nuñez-Anita, M. Cajero-Juárez, and V. M. Castaño, "Cytocompatible antifungal acrylic resin containing silver nanoparticles for dentures," International Journal of Nanomedicine, vol. 7, Article ID 4777, 2012.

[64] S.-M. Hasheminya and J. Dehghannya, "Green synthesis and characterization of copper nanoparticles using Eryngium caucasicum Trautv aqueous extracts and its antioxidant and antimicrobial properties," Particulate Science \& Technology, vol. 38, no. 8, pp. 1019-1026, 2020.

[65] S. Parthasarathy, S. Jayacumar, S. Chakraborty et al., "Fabrication and characterization of copper nanoparticles by green synthesis approach using Plectranthus amboinicus leaves extract," Research Square, vol. 7, no. 4, p. 16, 2020.

[66] P. Das, S. Ghosh, R. Ghosh, S. Dam, and M. Baskey, "Madhuca longifolia plant mediated green synthesis of cupric oxide nanoparticles: a promising environmentally sustainable material for waste water treatment and efficient antibacterial agent," Journal of Photochemistry and Photobiology B: Biology, vol. 189, pp. 66-73, 2018.

[67] N. Nagar and V. Devra, "Green synthesis and characterization of copper nanoparticles using Azadirachta indica leaves," Materials Chemistry and Physics, vol. 213, pp. 44-51, 2018.

[68] P. Padma, S. Banu, and S. Kumari, "Studies on green synthesis of copper nanoparticles using Punica granatum," Annual Research \& Review in Biology, vol. 23, no. 1, pp. 1-10, 2018.

[69] S. Shende, A. P. Ingle, A. Gade, and M. Rai, "Green synthesis of copper nanoparticles by Citrus medica Linn. (Idilimbu) juice and its antimicrobial activity," World Journal of Microbiology and Biotechnology, vol. 31, no. 6, pp. 865-873, 2015.

[70] W. Ahmad, K. Kumar Jaiswal, and M. Amjad, "Euphorbia herita leaf extract as a reducing agent in a facile green synthesis of iron oxide nanoparticles and antimicrobial activity evaluation," Inorganic and Nano-Metal Chemistry, vol. 51, pp. 1-8, 2020.

[71] S. Afsheen, M. B. Tahir, T. Iqbal, A. Liaqat, and M. Abrar, "Green synthesis and characterization of novel iron particles by using different extracts," Journal of Alloys and Compounds, vol. 732, pp. 935-944, 2018.

[72] C. Silveira, Q. L. Shimabuku, M. Fernandes Silva, and R. Bergamasco, "Iron-oxide nanoparticles by the green synthesis method using Moringa oleifera leaf extract for fluoride removal," Environmental Technology, vol. 39, no. 22, pp. 2926-2936, 2018.

[73] G. Sathishkumar, V. Logeshwaran, S. Sarathbabu et al., "Green synthesis of magnetic $\mathrm{Fe}_{3} \mathrm{O}_{4}$ nanoparticles using Couroupita guianensis Aubl. fruit extract for their antibacterial and cytotoxicity activities," Artificial Cells, Nanomedicine, and Biotechnology, vol. 46, no. 3, pp. 589-598, 2018.

[74] G. Kasthuri, A. N. Reddy, P. M. Roopa, and D. Zamare, "Application of green synthesized iron nanoparticles for enhanced antimicrobial activity of selected traditional and commonly exploited drug amoxicillin against Streptococcus mutans," Biosciences, Biotechnology Research Asia, vol. 14, no. 3, pp. 1135-1141, 2017.

[75] D. Achudhan, S. Vijayakumar, B. Malaikozhundan et al., "The antibacterial, antibiofilm, antifogging and mosquitocidal activities of titanium dioxide $\left(\mathrm{TiO}_{2}\right)$ nanoparticles 
green-synthesized using multiple plants extracts," Journal of Environmental Chemical Engineering, vol. 8, no. 6, Article ID 104521, 2020.

[76] D. V. Raorane, R. S. Chaughule, S. R. Pednekar, and A. Lokur, "Experimental synthesis of size-controlled $\mathrm{TiO}_{2}$ nanofillers and their possible use as composites in restorative dentistry," The Saudi dental journal, vol. 31, no. 2, pp. 194-203, 2019.

[77] R. Dobrucka, "Synthesis of titanium dioxide nanoparticles using Echinacea purpurea herba," Iranian Journal of Pharmaceutical Research: IJPR, vol. 16, no. 2, pp. 756-762, 2017.

[78] Z. Madadi and T. Bagheri Lotfabad, "Aqueous extract of Acanthophyllum laxiusculum roots as a renewable resource for green synthesis of nano-sized titanium dioxide using solgel method," Advanced Ceramics Progress, vol. 2, no. 1, pp. 26-31, 2016.

[79] Y. A. Selim, M. A. Azb, I. Ragab, and M. Abd El-Azim, "Green synthesis of zinc oxide nanoparticles using aqueous extract of deverra tortuosa and their cytotoxic activities," Scientific Reports, vol. 10, no. 1, pp. 3445-3449, 2020.

[80] R. Álvarez-Chimal, V. I. García-Pérez, M. A. Álvarez-Pérez, and J. Á. Arenas-Alatorre, "Green synthesis of $\mathrm{ZnO}$ nanoparticles using a Dysphania ambrosioides extract. Structural characterization and antibacterial properties," Materials Science and Engineering: C, vol. 118, Article ID 111540, 2021.

[81] M. Manokari, R. Latha, S. Priyadharshini, R. M. Cokul, P. Beniwal, and M. Shekhawat, "Green synthesis of zinc oxide nanoparticles from aqueous extracts of Sesamum indicum L. and their characterization," World News of Natural Sciences, vol. 23, pp. 200-210, 2019.

[82] E. Darvishi, D. Kahrizi, and E. Arkan, "Comparison of different properties of zinc oxide nanoparticles synthesized by the green (using Juglans regia L. leaf extract) and chemical methods," Journal of Molecular Liquids, vol. 286, Article ID 110831, 2019.

[83] A. Miri and M. Sarani, "Biosynthesis and cytotoxic study of synthesized zinc oxide nanoparticles using Salvadora persica," BioNanoScience, vol. 9, no. 1, pp. 164-171, 2019.

[84] A. Salimi, H.-R. Rahimi, H. Forootanfar, E. Jafari, A. Ameri, and M. Shakibaie, "Toxicity of microwave-assisted biosynthesized zinc nanoparticles in mice: a preliminary study," Artificial Cells, Nanomedicine, and Biotechnology, vol. 47, no. 1, pp. 1846-1858, 2019.

[85] J. Suresh, G. Pradheesh, V. Alexramani, M. Sundrarajan, and S. I. Hong, "Green synthesis and characterization of zinc oxide nanoparticle using insulin plant (Costus pictus D. Don) and investigation of its antimicrobial as well as anticancer activities," Advances in Natural Sciences: Nanoscience and Nanotechnology, vol. 9, no. 1, Article ID 015008, 2018.

[86] M. Noruzi, "Biosynthesis of gold nanoparticles using plant extracts," Bioprocess and Biosystems Engineering, vol. 38, no. 1, pp. 1-14, 2015.

[87] M. Zahoor, N. Nazir, M. Iftikhar et al., "A review on silver nanoparticles: classification, various methods of synthesis, and their potential roles in biomedical applications and water treatment," Water, vol. 13, no. 16, Article ID 2216, 2021.

[88] L. Castillo-Henríquez, K. Alfaro-Aguilar, and J. UgaldeÁlvarez, "Green synthesis of gold and silver nanoparticles from plant extracts and their possible applications as antimicrobial agents in the agricultural area," Nanomaterials (Basel), vol. 10, no. 9, 2020.
[89] S. Jain and M. S. Mehata, "Medicinal plant leaf extract and pure flavonoid mediated green synthesis of silver nanoparticles and their enhanced antibacterial property," Scientific Reports, vol. 7, no. 1, pp. 1-13, 2017.

[90] N. A. Hanan, H. I. Chiu, M. R. Ramachandran et al., "Cytotoxicity of plant-mediated synthesis of metallic nanoparticles: a systematic review," International Journal of Molecular Sciences, vol. 19, no. 6, Article ID 1725, 2018.

[91] V. T. Noronha, A. J. Paula, G. Durán et al., "Silver nanoparticles in dentistry," Dental Materials, vol. 33, no. 10, pp. 1110-1126, 2017.

[92] P. Chen, Z. Wu, A. Leung et al., "Fabrication of a silver nanoparticle-coated collagen membrane with anti-bacterial and anti-inflammatory activities for guided bone regeneration," Biomedical Materials, vol. 13, no. 6, Article ID 065014, 2018.

[93] C. Butrón Téllez Girón, J. F. Hernández Sierra, I. DeAlbaMontero, U. Peña MdlA, and F. Ruiz, "Therapeutic use of silver nanoparticles in the prevention and arrest of dental caries," Bioinorganic Chemistry and Applications, vol. 2020, Article ID 8882930, 7 pages, 2020.

[94] L. Cheng, M. D. Weir, H. H. K. Xu et al., "Effect of amorphous calcium phosphate and silver nanocomposites on dental plaque microcosm biofilms," Journal of Biomedical Materials Research Part B: Applied Biomaterials, vol. 100B, no. 5, pp. 1378-1386, 2012.

[95] S. Adapa, "A Review on silver nanoparticles-The powerful nanoweapon against oral pathogens," International Journal of Oral Health Sciences, vol. 10, no. 1, pp. 6-12, 2020.

[96] Y. Shantiaee, F. Maziar, O. Dianat, and F. Mahjour, "Comparing microleakage in root canals obturated with nanosilver coated gutta-percha to standard gutta-percha by two different methods," Iranian Endodontic Journal, vol. 6, no. 4, pp. 140-5, Article ID 140, 2011.

[97] M. Samiei, M. Aghazadeh, M. Lotfi, S. Shakoei, Z. Aghazadeh, and S. M. Vahid Pakdel, "Antimicrobial efficacy of mineral trioxide aggregate with and without silver nanoparticles," Iranian Endodontic Journal, vol. 8, no. 4, pp. 166-70, Article ID 166, 2013.

[98] L. Zhao, H. Wang, K. Huo et al., "Antibacterial nanostructured titania coating incorporated with silver nanoparticles," Biomaterials, vol. 32, no. 24, pp. 5706-5716, 2011.

[99] C. T. Rodrigues, F. B. de Andrade, L. R. S. M. de Vasconcelos et al., "Antibacterial properties of silver nanoparticles as a root canal irrigant against Enterococcus faecalis biofilm and infected dentinal tubules," International Endodontic Journal, vol. 51, no. 8, pp. 901-911, 2018.

[100] R. A. Bapat, T. V. Chaubal, C. P. Joshi et al., "An overview of application of silver nanoparticles for biomaterials in dentistry," Materials Science and Engineering: C, vol. 91, pp. 881-898, 2018.

[101] A. Akhavan, A. Sodagar, F. Mojtahedzadeh, and K. Sodagar, "Investigating the effect of incorporating nanosilver/nanohydroxyapatite particles on the shear bond strength of orthodontic adhesives," Acta Odontologica Scandinavica, vol. 71, pp. 1038-42, 2013.

[102] A. P. R. Magalhães, L. B. Santos, L. G. Lopes et al., "Nanosilver application in dental cements," ISRN Nanotechnology, vol. 2012, Article ID 365438, 6 pages, 2012.

[103] M. Rafique, I. Sadaf, M. S. Rafique, and M. B. Tahir, "A review on green synthesis of silver nanoparticles and their applications," Artificial cells, nanomedicine, and biotechnology, vol. 45, no. 7, pp. 1272-1291, 2017. 
[104] S. M. Pourmortazavi, M. Taghdiri, V. Makari, M. RahimiNasrabadi, and H. Batooli, "Reducing power of Eucalyptus oleosaleaf extracts and green synthesis of gold nanoparticles using the extract," International Journal of Food Properties, vol. 20, no. 5, pp. 1097-1103, 2017.

[105] R. A. Bapat, T. V. Chaubal, S. Dharmadhikari et al., "Recent advances of gold nanoparticles as biomaterial in dentistry," International Journal of Pharmaceutics, vol. 586, Article ID 119596, 2020.

[106] S. R. Park, H. W. Lee, J. W. Hong et al., "Enhancement of the killing effect of low-temperature plasma on Streptococcus mutans by combined treatment with gold nanoparticles," Journal of Nanobiotechnology, vol. 12, no. 1, Article ID 29, 2014.

[107] Y. Xia, H. Chen, F. Zhang et al., "Gold nanoparticles in injectable calcium phosphate cement enhance osteogenic differentiation of human dental pulp stem cells," Nanomedicine: Nanotechnology, Biology and Medicine, vol. 14, no. 1, pp. 35-45, 2018.

[108] S. Dadkan, S. Salari, M. Khakbiz, and M. Atai, "Mechanical properties of dental adhesives containing gold nano particles," in Proceedings of the 5th International Congress on Nanoscience \& Nanotechnology (ICNN2014), Tehran, Iran, 2014.

[109] Y. Wu, M. R. K. Ali, K. Chen, N. Fang, and M. A. El-Sayed, "Gold nanoparticles in biological optical imaging," Nano Today, vol. 24, pp. 120-140, 2019.

[110] K. Sharma and C. Chauhan, "Role of magnetic nanoparticle (MNPs) in cancer treatment: a review," Materials Today Proceedings, 2021, In press.

[111] M. Suciu, C. M. Ionescu, A. Ciorita et al., "Applications of superparamagnetic iron oxide nanoparticles in drug and therapeutic delivery, and biotechnological advancements," Beilstein Journal of Nanotechnology, vol. 11, no. 1, pp. 1092-1109, 2020.

[112] S. S. Salem and A. Fouda, "Green synthesis of metallic nanoparticles and their prospective biotechnological applications: an overview," Biological Trace Element Research, vol. 199, no. 1, pp. 344-370, 2021.

[113] R. Jain, S. Mendiratta, L. Kumar, and A. Srivastava, "Green synthesis of iron nanoparticles using Artocarpus heterophyllus peel extract and their application as a heterogeneous Fenton-like catalyst for the degradation of Fuchsin Basic dye," Current Research in Green and Sustainable Chemistry, vol. 4, Article ID 100086, 2021.

[114] M. Ahmadi, "Iron oxide nanoparticles for delivery purposes," in Nanoengineered Biomaterials for Advanced Drug Delivery, M. Mozafari, Ed., Elsevier, Amsterdam, Netherlands, pp. 373-393, 2020.

[115] L. Gao, Y. Liu, D. Kim et al., "Nanocatalysts promote Streptococcus mutans biofilm matrix degradation and enhance bacterial killing to suppress dental caries in vivo," Biomaterials, vol. 101, pp. 272-284, 2016.

[116] A. Król, P. Pomastowski, K. Rafińska, V. Railean-Plugaru, and B. Buszewski, "Zinc oxide nanoparticles: synthesis, antiseptic activity and toxicity mechanism," Advances in Colloid and Interface Science, vol. 249, pp. 37-52, 2017.

[117] S. Kaliamurthi, G. Selvaraj, Z. E. Cakmak, A. D. Korkmaz, and T. Cakmak, "The relationship between Chlorella sp. and zinc oxide nanoparticles: changes in biochemical, oxygen evolution, and lipid production ability," Process Biochemistry, vol. 85, pp. 43-50, 2019.

[118] J. Qu, X. Yuan, X. Wang, and P. Shao, "Zinc accumulation and synthesis of $\mathrm{ZnO}$ nanoparticles using Physalis alkekengi
L," Environmental Pollution, vol. 159, no. 7, pp. 1783-1788, 2011.

[119] Y. Li, Y. Yang, Y. Qing et al., "Enhancing ZnO-NP antibacterial and osteogenesis properties in orthopedic applications: a review," International Journal of Nanomedicine, vol. 15, pp. 6247-6262, 2020.

[120] M. Anbuvannan, M. Ramesh, G. Viruthagiri, N. Shanmugam, and N. Kannadasan, "Anisochilus carnosus leaf extract mediated synthesis of zinc oxide nanoparticles for antibacterial and photocatalytic activities," Materials Science in Semiconductor Processing, vol. 39, pp. 621-628, 2015.

[121] L. Fu and Z. Fu, "Plectranthus amboinicus leaf extractassisted biosynthesis of $\mathrm{ZnO}$ nanoparticles and their photocatalytic activity," Ceramics International, vol. 41, no. 2, pp. 2492-2496, 2015.

[122] S. Ambika and M. Sundrarajan, "Antibacterial behaviour of Vitex negundo extract assisted $\mathrm{ZnO}$ nanoparticles against pathogenic bacteria," Journal of Photochemistry and Photobiology B: Biology, vol. 146, pp. 52-57, 2015.

[123] H. Agarwal, S. Venkat Kumar, and S. Rajeshkumar, "A review on green synthesis of zinc oxide nanoparticles-an ecofriendly approach," Resource-Efficient Technologies, vol. 3, no. 4, pp. 406-413, 2017.

[124] A. Baranwal, A. Srivastava, P. Kumar, V. K. Bajpai, P. K. Maurya, and P. Chandra, "Prospects of nanostructure materials and their composites as antimicrobial agents," Frontiers in Microbiology, vol. 9, Article ID 422, 2018.

[125] Y. Li, Y. Yang, Y. A. Qing et al., "Enhancing ZnO-NP antibacterial and osteogenesis properties in orthopedic applications: a review," International Journal of Nanomedicine, vol. 15, pp. 6247-6262, 2020.

[126] V. Andrade, A. Martínez, N. Rojas et al., “Antibacterial activity against Streptococcus mutans and diametrical tensile strength of an interim cement modified with zinc oxide nanoparticles and terpenes: an in vitro study," The Journal of Prosthetic Dentistry, vol. 119, no. 5, pp. e1-862, Article ID 862, 2018.

[127] E. Elizabeth, G. Baranwal, A. G. Krishnan, D. Menon, and M. Nair, "ZnO nanoparticle incorporated nanostructured metallic titanium for increased mesenchymal stem cell response and antibacterial activity," Nanotechnology, vol. 25, no. 11, Article ID 115101, 2014.

[128] W. Artifon, S. M. Pasini, A. Valério, S. Y. G. González, S. M. de Arruda Guelli Ulson de Souza, and A. A. U. de Souza, "Harsh environment resistant-antibacterial zinc oxide/Polyetherimide electrospun composite scaffolds," Materials Science \& Engineering. C, Materials for Biological Applications, vol. 103, Article ID 109859, 2019.

[129] M. Nadeem, D. Tungmunnithum, C. Hano et al., "The current trends in the green syntheses of titanium oxide nanoparticles and their applications," Green Chemistry Letters and Reviews, vol. 11, no. 4, pp. 492-502, 2018.

[130] G. Nabi, N. Qurat-ul-Aain, N. R. Khalid et al., "A review on novel eco-friendly green approach to synthesis $\mathrm{TiO}_{2}$ nanoparticles using different extracts," Journal of Inorganic and Organometallic Polymers and Materials, vol. 28, no. 4, pp. 1552-1564, 2018.

[131] W. Ahmad, K. K. Jaiswal, and S. Soni, "Green synthesis of titanium dioxide $\left(\mathrm{TiO}_{2}\right)$ nanoparticles by using Mentha arvensis leaves extract and its antimicrobial properties," Inorganic and Nano-Metal Chemistry, vol. 50, no. 10, pp. 1032-1038, 2020. 
[132] J. Sun, E. J. Petersen, S. S. Watson et al., "Biophysical characterization of functionalized titania nanoparticles and their application in dental adhesives," Acta Biomaterialia, vol. 53, pp. 585-597, 2017.

[133] M. Alamgir, A. Mallick, G. C. Nayak, and S. K. Tiwari, "Development of $\mathrm{PMMA} / \mathrm{TiO}_{2}$ nanocomposites as excellent dental materials," Journal of Mechanical Science and Technology, vol. 33, no. 10, pp. 4755-4760, 2019.

[134] D. Ziental, B. Czarczynska-Goslinska, D. T. Mlynarczyk et al., "Titanium dioxide nanoparticles: prospects and applications in medicine," Nanomaterials, vol. 10, no. 2, Article ID 387, 2020.

[135] M. I. Din and R. Rehan, "Synthesis, characterization, and applications of copper nanoparticles," Analytical Letters, vol. 50, no. 1, pp. 50-62, 2017.

[136] D. Letchumanan, S. P. M. Sok, S. Ibrahim, N. H. Nagoor, and N. M. Arshad, "Plant-based biosynthesis of copper/copper oxide nanoparticles: an update on their applications in biomedicine, mechanisms, and toxicity," Biomolecules, vol. 11, no. 4, Article ID 564, 2021.

[137] M. Rafique, A. J. Shaikh, R. Rasheed et al., "A review on synthesis, characterization and applications of copper nanoparticles using green method," Nano, vol. 12, no. 4, Article ID 1750043, 2017.

[138] M. Fernández-Arias, M. Boutinguiza, J. Del Val et al., "Copper nanoparticles obtained by laser ablation in liquids as bactericidal agent for dental applications," Applied Surface Science, vol. 507, Article ID 145032, 2020.

[139] W. G. Renné, A. Lindner, A. S. Mennito et al., "Antibacterial properties of copper iodide-doped glass ionomer-based materials and effect of copper iodide nanoparticles on collagen degradation," Clinical Oral Investigations, vol. 21, no. 1, pp. 369-379, 2017.

[140] M. F. Gutiérrez, L. F. Alegría-Acevedo, L. Méndez-Bauer et al., "Biological, mechanical and adhesive properties of universal adhesives containing zinc and copper nanoparticles," Journal of Dentistry, vol. 82, pp. 45-55, 2019. 